\title{
Towards a pan-Arctic inventory of the species diversity of the macro- and megabenthic fauna of the Arctic shelf seas
}

Piepenburg $\mathrm{D}^{1}$, Archambault $\mathrm{P}^{2}$, Ambrose $\mathrm{Jr} \mathrm{WG}^{3,5}$, Blanchard $\mathrm{AL}^{4}$, Bluhm $\mathrm{BA}^{4}$, Carroll $\mathrm{ML}^{5}$, Conlan $\mathrm{KE}^{6}$, Cusson $\mathrm{M}^{7}$, Feder $\mathrm{HM}^{4}$, Grebmeier JM${ }^{8}$, Jewett $\mathrm{SC}^{4}$, Lévesque $\mathrm{M}^{2}$, Petryashev VV ${ }^{9}$, Sejr $\mathrm{MK}^{10}$, Sirenko $\mathrm{BI}^{9}$, Włodarska-Kowalczuk $\mathrm{M}^{11}$

${ }^{1}$ Mainz Academy of Sciences, Humanities and Literature, c/o, Institute for Polar Ecology, University of Kiel, D24148 Kiel, Germany; Email: dpiepenburg@ipoe.uni-kiel.de; Phone: +49 431600 1264; Fax: +49 4316001210 ${ }^{2}$ Insitut des Sciences de la Mer de Rimouski, Université du Québec à Rimouski, Rimouski, Quebec G5L 3A1, Canada

${ }^{3}$ Department of Biology, Bates College, Lewiston, ME 04240, USA

${ }^{4}$ Insitute of Marine Science, University of Alaska Fairbanks, Fairbanks, AK 99775-7220, USA

${ }^{5}$ Akvaplan-niva, Polar Environmental Centre, N-9296 Tromsø, Norway

${ }^{6}$ Canadian Museum of Nature, P. O. Box 3443, Station D, Ottawa, Ontario K1P 6P4, Canada

${ }^{7}$ Département des Sciences Fondamentales, Université du Québec à Chicoutimi, Chicoutimi, Quebec G7H 2B1, Canada

${ }^{8}$ Chesapeake Biological Laboratory, University of Maryland, Solomons, MD 20688, USA

${ }^{9}$ Laboratory of Marine Researches, Zoological Institute RAS, St. Petersburg, 199034, Russia

${ }^{10}$ National Environmental Research Institute, University of Aarhus, Aarhus, DK-8600, Denmark

${ }^{11}$ Department of Marine Ecology, Institute of Oceanology PAS, Sopot, 81-712, Poland

\begin{abstract}
Although knowledge of Arctic seas has increased tremendously in the past decade, benthic diversity was investigated at regional scales only, and no attempt had been made to examine it across the entire Arctic. We present a first pan-Arctic account of the species diversity of the macro- and megabenthic fauna of the Arctic marginal shelf seas. It is based on an analysis of 25 published and unpublished species-level data sets, together encompassing 14 of the 19 marine Arctic shelf ecoregions and comprising a total of 2636 species, including 847 Arthropoda, 668 Annelida, 392 Mollusca, 228 Echinodermata, and 501 species of other phyla. For the four major phyla, we also analyze the differences in faunal composition and diversity among the ecoregions. Furthermore, we compute gross estimates of the expected species numbers of these phyla on a regional scale. Extrapolated to the entire fauna and study area, we arrive at the conservative estimate that 3900 to 4700 macro- and megabenthic species can be expected to occur on the Arctic shelves. These numbers are smaller than analogous estimates for the Antarctic shelf but the difference is on the order of about two and thus less pronounced than previously assumed. On a global scale, the Arctic shelves are characterized by intermediate macro- and megabenthic species numbers. Our preliminary pan-Arctic inventory provides an urgently needed assessment of current diversity patterns that can be used by future investigations for evaluating the effects of climate change and anthropogenic activities in the Arctic.
\end{abstract}

Keywords: Arctic, macrobenthos, megabenthos, shelf, pan-Arctic inventory, diversity 


\section{Introduction}

\section{Background}

The circum-Arctic shelf seas are generally characterized by pronounced seasonality in solar radiation and nutrient availability, as well as long-lasting ice cover and water temperatures close to the freezing point (Carmack and Wassmann 2006). Furthermore, the northernmost regions are limited in their connections with adjacent boreal regions (Curtis 1975).

Consequently, Arctic seas have long been considered to be among the most hostile habitats on Earth and, hence, the poorest regions, in terms of biodiversity, of the world's oceans (Hempel 1985).

The low species diversity of the Arctic benthic biota is often contrasted to highly diverse Antarctic benthos. The differences between the two polar regions are attributed to several factors, including the 'harshness' and relative homogeneity of Arctic benthic habitats, the younger geological age and less pronounced biogeographic isolation of the Arctic marine environments or the predominance of hard-bottom habitats, inhabited by rich epifaunal assemblages, on the Antarctic shelves (Dayton 1990; Clarke and Crame 1992; Sirenko 2009).

\section{Motivation}

The paradigm of low Arctic diversity, as opposed to highly diverse Antarctic fauna, has recently been questioned (Piepenburg 2005; Włodarska-Kowalczuk et al. 2007). Moreover, regional studies in the European sector have failed to document decreasing biodiversity with higher latitudes (e.g., Kendall and Aschan 1993; Renaud et al. 2009). The notion of a comparatively poor Arctic was actually supported by limited data, as the knowledge of the composition of Arctic sea life was still inadequate due to the logistical constraints resulting from the remoteness, inhospitable climate, and heavy ice cover characterizing the region (Carmack et al. 2006). Hence, comprehensive species inventories and comparisons of biodiversity among Arctic regions were relatively scarce (Zenkevitch 1963; Curtis 1975).

Our knowledge on Arctic seas has increased tremendously in the past two decades as a result of novel sampling efforts made possible for several reasons, such as the availability of new research ice breakers and the political opening of the vast Russian Arctic regions to international research efforts after a decade-long period of isolation. Although it is commonly acknowledged that there is an urgent need to address biodiversity patterns at larger scales (i.e., the entire Arctic; Piepenburg 2005), most biodiversity research on the Arctic benthos has 
mainly focused at local to regional scales (e.g., MacGinitie 1955; Feder et al. 1994, 2005, 2007; Denisenko 2003; Sirenko 2004; Bluhm et al. 2005; Conlan and Kvitek 2005; Cusson et al. 2007). Nevertheless, Zenkevitch (1963), Sirenko and Piepenburg (1994) and Sirenko (2001) provided large-scale inventories of the macrozoobenthic diversity of the entire eastern (Eurasian) Arctic. A truly circum-Arctic biodiversity census, however, is currently not available.

\section{Objectives}

We present the first pan-Arctic inventory of the species diversity (more precisely: the species numbers) of the benthic fauna of the marginal shelf seas of the eastern (Eurasian) and western (North American) Arctic. Our study is confined to 'large' seabed animals, the macro- and megafaunal benthos. According to a well-established operational definition proposed by Gage and Tyler (1991), this ecological group encompasses those seafloor organisms that are large enough to be retained on sieves with a mesh size of $0.5 \mathrm{~mm}$ (macrobenthos, mostly infaunal) or to be visible in seabed images and/or to be caught by towed sampling gear (megabenthos, mostly epifaunal). Moreover, our census covers only invertebrate taxa, fishes were not considered.

Instead of only reviewing published biodiversity reports we performed a synoptic numerical analysis of published and unpublished data compiled in the Arctic Ocean Diversity database (www.arcodiv.org) and contributed by the authors of this paper. Our primary goals were to produce up-to-date and comprehensive information on the current knowledge of what lives on the seabed of Arctic shelves and to analyze large-scale spatial patterns across the Arctic shelf regions for the most widely distributed diverse and abundant phyla (Annelida, Mollusca, , Arthropoda, and Echinodermata).

More specifically, the issues addressed in this paper are:

(1) Summarizing on a pan-Arctic scale the current state of knowledge of the diversity of the macro- and megafaunal seabed fauna of shelf seas

(2) Assessing the total number of macro- and megabenthic species known from the Arctic shelves

(3) Estimating the total number of macro- and megabenthic species expected to occur on Arctic shelves 
(4) Describing spatial distribution patterns of benthic diversity and comparing the faunal composition among Arctic shelf regions (for dominant phyla)

These objectives required the compilation and validation of species lists from a broad range of regions for all major macro- and megabenthic taxa. The resulting database was then analyzed for spatial trends in species diversity and distribution among major regional units.

Our census provides an urgently needed assessment of current diversity patterns that can be used by future biodiversity investigations evaluating and predicting the effects of rapid climate change or increasing anthropogenic activities (e.g., exploration and exploitation of natural resources, coastal development, shipping, tourism) in the Arctic.

\section{Material and methods}

\section{Definition of the study area}

We use a definition of 'Arctic seas' that is largely based on a widely accepted scheme proposed by the Arctic Monitoring and Assessment Programme (AMAP) (1998). The AMAP boundary of the Arctic, however, extends down to southern Norway's west coast, through the Norwegian and into the North Seas, which we do not regard as being 'Arctic'. Consequently, as an exception of the AMAP approach, we define the Arctic Circle $\left(66^{\circ} 33.5^{\prime} \mathrm{N}\right)$ as the southern boundary of our study area in the northeastern Atlantic, thus excluding the waters off southern Iceland and off mid- and south Norway (while South Greenland is still included). The southeastern Bering Sea is also included, as the Arctic shelf extends from the Chukchi Sea through the Bering Sea to the Aleutian Islands.

Our analysis is confined to Arctic shelf regions and complements similar investigations on the benthos of Arctic coastal waters and fjords (Weslawski et al. this volume) and the Arctic deep sea (Bluhm et al. this volume). As the boundary between shelf and deep sea we chose the shelf break, represented by a rapid increase in depth with distance off shore, which occurs at different water depths in the various seas but was always $<500 \mathrm{~m}$ (Jakobsson 2002). The distinction between Arctic shelf and coastal areas was more difficult to define. Here, we excluded stations that are both closer than $10 \mathrm{~km}$ to shore and shallower than $30 \mathrm{~m}$. This approach is based on the assumption that these are 'coastal' sites, which are under the strongest influence of wave action, ice scourer, land discharge of freshwater and sediments and where the seabed is within the euphotic zone. We acknowledge that this boundary is to 
some extent arbitrary and that some overlap of the shelf and coastal inventory is inevitable, especially in the Canadian Archipelago.

As a result, our study area largely comprises the Arctic shelf regions, the geographic boundaries of which are defined according to the "IHO Arctic Ocean Provinces" (International Hydrographic Organization 2001) and minor modifications suggested by Jakobsson (2002). From an ecological point of view, the shelf seas represent marine ecoregions, which are defined as "distinct areas of relatively homogeneous species composition, which is likely to be determined by the predominance of a small number of ecosystems and/or a distinct suite of oceanographic or topographic features" (Spalding et al. 2007). According to Spalding et al. (2007) "the dominant biogeographic forcing agents defining the ecoregions vary from location to location but may include isolation, upwelling, nutrient inputs, freshwater influx, temperature regimes, ice regimes, exposure, sediments, currents, and bathymetric and coastal complexity" (as well as biological factors such as interspecific interactions and dispersal). Following this approach, nineteen shelf ecoregions, ranging widely in areal extent from $79,000 \mathrm{~km}^{2}$ (North and East Iceland) to $1,536,000 \mathrm{~km}^{2}$ (North and East Barents Sea), are distinguished in the Arctic realm (Table 1, Fig. 1).

Together, the Arctic shelf ecoregions comprise more than half of the Arctic Ocean, as defined by the International Hydrographic Organization (2001). Although they are characterized by a number of general similarities in the environmental setting (Hempel 1985), there are also some ecologically important contrasts between them, due to differences in geographical position, topography, bathymetry, climate, hydrography, sea ice dynamics, and terrestrial impact, as described in detail in a number of review articles, e.g., Curtis (1975), Dayton (1990), Grebmeier and Barry (1991), Carmack et al. (2006), and Witman et al. (2008).

\section{Data compilation}

We compiled an Arctic biodiversity database, representing species collected across the various regions of the entire study area, from a total of 25 sources (the ArcOD database, published literature as well as yet unpublished scientific cruise data provided by the authors: Anonymous (1978); Archambault et al. (subm); Atkinson and Wacasey (1989a,b); Bluhm et al. (1998, 2009); Brandt et al. (1996); Carey (1981); Carroll et al. (2008); Cochrane et al. (2009); Conlan et al. (2008); Cusson et al. (2007); Feder et al. (1980, 2005, 2007); Hopky et al. (1994); Lalande (2003); MacLaren MAREX (1978); Piepenburg (1988); Piepenburg et al. (1996); Schnack (1998); Sejr et al. (2000, 2010); Starmans et al. (1993); Steffens et al. 
(2006); Wacasey et al. (1976, 1977, 1979, 1980); Wenzel (2007); Włodarska-Kowalczuk et al. (2004); see Table A in the Electronic Supplementary Material of this paper). Each 'record' is a taxon (i.e., a species or a higher taxonomic group in case species identification was not possible), which was reported from a georeferenced sample, such as a trawl, epibenthic sledge, grab, core, seabed photograph, or ROV video footage, and which was identified based on morphological characteristics. The final database contained 65,138 records of 4900 taxa from 4452 stations (i.e., locations), distributed across 18 of the 19 Arctic ecoregions (Table 1). The unpublished data sets considered in this study will be transferred to the Arctic Ocean Diversity (ArcOD) database and will thus be available for public interactive searches through both the Ocean Biogeographic Information System (OBIS) and the Global Biodiversity Information System (GBIF) web portals.

\section{Data validation}

The use of both accepted species names and unaccepted synonyms confounds cross-dataset comparability, especially between Russian and 'western' investigations. Therefore, we consistently used the valid species names according to the World Register of Marine Species (WoRMS; http://www.marinespecies.org/). All species names in the data sets provided by the contributors were submitted to WoRMS' Taxon Match online tool. Spelling errors were corrected and information not part of the Latin binomial were excluded (i.e., 'cf.', 'nondeterm', 'indeterm', 'type 1', 'var.'). All records were excluded that represent higher taxa (genera, families, orders) and clearly encompassed several species (as other species of this higher taxon were also in the station data). Therefore, in the validated data set each record represents, to our best knowledge, a single species, even in case it was not possible to assign a definite species name to it. For taxa identified by WoRMS as ambiguous, an arbitrary choice was often made, usually based on the first name presented. The taxon match tool was also used to extract the taxonomic hierarchy (phylum to subspecies), which is needed for the computation of taxonomic distinctness values. Several names not listed in WoRMS were listed on the uBio web portal, usually leading to their synonym entries in the ITIS database. Taxa with no available synonym in WoRMS were left unchanged (retaining the original name), because WoRMS is not complete yet.

After this matching procedure, the unique species list amounted to approximately half of the total list of taxon names in the original combined data sets (2636 species compared to about 4900 taxa). The reduction of record numbers after performing the quality control procedures was similar in magnitude to those documented in other large-scale dataset 
compilations, e.g., in a pan-European compilation of the Marbef LargeNet project dataset (Vandepitte et al. 2010).

\section{Data aggregation}

Initial data analyses showed that a 'station' does not have the same meaning across the entire database: it can represent quite a comprehensive inventory of the whole macro- and megabenthic community present at a location, encompassing dozens of species from a broad variety of phyla, or be a unique sample of a single or a few species. Therefore, comparative analyses at 'station' level would be severely biased and are thus not meaningful. This also means that the number of stations per unit area, e.g., per ecoregion, is not a consistent measure of sampling effort.

Nonetheless, it is evident that the number of stations varied considerably among the ecoregions (Table 1). Five ecoregions were particularly poorly represented in our data, i.e., present with only 0-17 stations or less than 100 records (North and East Iceland, Northern Grand Banks - Southern Labrador, Lancaster Sound, Baffin Bay, and the High Arctic Archipelago) and hence they were not considered in the comparative analyses. It should be noted, however, that the number of stations primarily quantifies data availability to this study, which does not necessarily reflect real sampling intensity. While some poorly represented regions are truly little studied, such as the High Arctic Archipelago, others are actually well covered in a number of studies, such as the Northern Grand Banks - Southern Labrador (Archambault et al. submitted), the southeastern Bering Sea (Feder et al. 1980, 1982; Haflinger 1981), but are not sufficiently represented in our database, partly because these regions where not considered as being 'Arctic' before we started the compilation. The total number of stations from the remaining 14 regions amounted to 4419, and the number of stations from individual ecoregions ranged between 19 from North Greenland to 1799 from the North and East Barents Sea (Table 1).

To minimize the bias introduced by uneven sampling effort and by different sampling methods, we confined our synoptic analyses to presence-absence data and aggregated the records by larger spatial units, i.e., the ecoregions outlined above.

\section{Data analyses}

Two metrics were used to quantify biodiversity. First, the number of species (S) was determined, at the scales of both the entire study area and ecoregions. Since S is very sensitive 
to sampling effort, we also calculated the average taxonomic distinctness $\left(\Delta^{+}\right)$using the PRIMER software (Version 6; Clarke and Gorley 2006). This presence/absence-based measure quantifies a further trait of biodiversity, which Clarke and Warwick (2001) termed as the "taxonomic breadth" (i.e., the average evolutionary distance between species) of a sample or area. $\Delta^{+}$describes the average 'path length' between two species following Linnean taxonomy of all species within a studied sample or area. Seven taxonomic levels were used in calculations: species, genus, family, order, class, phylum, and kingdom, and equal step levels between successive taxonomic levels were assumed. Being largely independent of both species number and sample number, taxonomic distinctness measures are particularly suited for comparisons of historic data sets, for which sampling effort is uncontrolled, unknown or unequal (Clarke and Warwick 2001a), as is the case for the between-ecoregion analyses.

Even at a spatial level as coarse as that of ecoregions, both the sampling effort and the overall taxonomic comprehensiveness of the faunal inventories varied greatly. From both the White and Kara Seas, for instance, only reports of species from a rather narrow taxonomic range, encompassing three major phyla (Mollusca, Arthropoda, and Echinodermata), are included in our database, whereas there are no data on all other taxa. In contrast, the records from other regions include a greater taxonomic breadth. Due to this pronounced unevenness in the taxonomic census range, comparative analyses of diversity and faunal composition across all taxa in our data would inevitably provide misleading results. Therefore, we performed two separate between-ecoregion analyses limited to taxa that were most comprehensively represented in our dataset: (1) one that was confined to the three dominant phyla Mollusca, Arthropoda, and Echinodermata (MAE; encompassing a total of 1467 species from 4417 stations), which were present in each of the 14 ecoregions considered here, and (2) another one for only Annelida ( $A$; encompassing 668 species from 3662 stations), for which data were available from 12 ecoregions.

Values of average taxonomic distinctness of the mollusk, arthropod and echinoderm faunas and the annelid faunas observed in the studied ecoregions were compared to the expected mean $\Delta^{+}$values and 0.95 probability limits, which were computed for 1000 randomized frequency-based simulations of sub-samples of varying size (10 to 600 species and 10 to 400 species, respectively) drawn from a 'pan-Arctic' species pool consisting of the total of 1467 $M A E$ species and $668 A$ species contained in our dataset by means of the PRIMER software (Clarke and Gorley 2006). 
Station-based rarefaction curves, which are equivalent of 'randomized' or 'smoothed' species accumulation curves (Gotelli and Colwell 2001), were used as a further tool to compare species numbers among ecoregions differing widely in sampling effort (Clarke and Warwick 2001b). They were generated by means of the PRIMER software as averages of 400 species accumulation curves based on randomly permuted order of samples (Clarke and Gorley 2006). Furthermore, we computed from the station-based rarefaction curves the rarefied numbers of species that are expected to be recorded in an ecoregion after taking samples at only 19 stations $\left(\mathrm{RS}_{19}\right.$, with 19 being the minimum number of stations from an ecoregion in our dataset).

We computed non-parametric Chao2 estimators by means of the PRIMER software (Clarke and Gorley 2006) to predict the expected number of species, which would be observed for an infinite number of samples, for both $M A E$ and $A$ for each ecoregion. This parameter is based on the number of 'rare' species in the ecoregion data sets (Chao2 $=S_{o b s}+Q_{1}{ }^{2} / 2 Q_{2}$, where $S_{o b s}$ is the total number of observed species, $Q_{1}$ the number of species that occur at just one station (uniques) and $Q_{2}$ the number of species that occur at exactly two stations (duplicates); Chao 1987).

The regional patterns in multivariate faunal resemblance, quantified by the Sorensen (or Dice) coefficient, were visualized by means of Multidimensional Scaling (MDS; Clarke and Warwick 2001b) for $M A E$ as well as $A$. In addition to the species-based analyses, the distribution patterns for data aggregated to higher taxonomic levels (genus, family) were also examined. This approach is assumed to be more appropriate for our data set because it can be expected to be less biased than species-based analyses, particularly when looking at finer spatial levels such as that of ecoregions. The lowering of taxonomic resolution of data can be advantageous for the analyses of large databases containing several datasets that can be inconsistent in the accuracy of species-level identifications. Several studies have demonstrated taxonomic sufficiency of genera and families for detecting major discontinuities in benthic distributions (e.g., Cusson et al. 2007; Włodarska-Kowalczuk and Kedra 2007).

In a second-stage approach, the relationships among the between-ecoregion similarities (computed based on the distribution of mollusks, arthropods, echinoderms, treated both separately and combined (MAE), as well as annelids $(A)$ analyzed at species, genera and families level each) were examined using the Spearman's rank correlation coefficient ( $\rho$ ) computed between corresponding elements of the first-stage similarity matrices. The resemblances among the first-stage between-ecoregion similarities were compared using the 
method of Somerfield and Clarke (1995), resulting in a second-stage MDS ordination showing the degree of concordance in the spatial distribution patterns of Mollusca, Annelida, Arthropoda, and Echinodermata assessed at various taxonomic levels, and the statistical significance of the resemblance concordances was tested by means of the RELATE routine. All computations were performed with the PRIMER software (Clarke and Gorley 2006).

\section{Results}

\section{Overall inventory}

Our joint database, covering 14 of 19 marine shelf ecoregions of the Arctic, comprises a total of 2636 benthic species, including 847 Arthropoda (32\%), 668 Annelida (25\%), 392 Mollusca (15\%), 228 Echinodermata (9\%), 205 Bryozoa (8\%), and 296 (11\%) species of other phyla (Fig. 2; see also Table B in the Electronic Supplementary Material of this paper).

Within the Arthropoda, Malacostraca are the most diverse class with 805 species (including 494 Amphipoda, 112 Isopoda, 26 Tanaidacea, 88 Cumacea, and 61 Decapoda), followed by Pycnogonida (29) and Maxillopoda (11) (Fig. 2). The composition of the mollusk fauna is strongly dominated by Gastropoda (205) and Bivalvia (156) (Fig. 2). Most annelid species belong to the Polychaeta (659) (Fig. 2). The major echinoderm classes are Ophiuroidea (98 species), followed by Asteroidea (61), Holothuroidea (53), Echinoidea (11), and Crinoidea (5) (Fig. 2).

\section{Most common species}

The most widely distributed species (i.e., those occurring in at least 13 of the 14 ecoregions considered in our analysis) are the brittle stars Ophiocten sericeum, Ophiura robusta, and Ophiacantha bidentata, the amphipods Ampelisca eschrichti, Anonyx nugax, Arrhis phyllonyx, Byblis gaimardi, and Haploops tubicola, and the cumaceans Diastylis spp. and Leucon nasica.

The most common mollusks, occurring in at least 12 of 14 ecoregions, are the bivalves Astarte montagui, Macoma calcarea, Musculus niger, Serripes groenlandicus, and Yoldiella lenticula.

Among the polychaetes, the species Nothria conchylega, Aglaophamus malmgreni, Eteone longa, Lumbrineris fragilis, Nicomache lumbricalis, Pholoe minuta, and Scalibregma 
inflatum are most widely distributed (i.e., reported from at least 10 of the 12 ecoregions, for which polychaete distribution data are available).

\section{Diversity comparisons between ecoregions}

In our data, the number of Mollusca, Arthropoda, and Echinodermata (hereafter called MAE) species recorded in individual ecoregions ranged from 40 for the East Greenland shelf to 595 for the NE Barents Sea (Table 2a, Fig. 3a). Average MAE taxonomic distinctness values $\left(\Delta^{+}\right)$ computed for the ecoregions were in the range from 67.5 in the Kara Sea to 72.5 in the Eastern Bering Sea (Table 2a). The numbers of annelid species (hereafter called $A$ ) in the ecoregions varied between 24 in the eastern Bering Sea and 322 in North and East Barents Sea (Table 2b, Fig. 3b). The annelid $\Delta^{+}$values ranged from 54.0 in the Laptev Sea to 55.3 in the Eastern Bering Sea (Table 2b).

Both diversity parameters, total numbers of species $(\mathrm{S})$ recorded in the ecoregions and average taxonomic distinctness $\left(\Delta^{+}\right)$, tend to increase with sampling effort, approximated by the total number of stations from each ecoregion. These relationships are, however, rather weak, for $\Delta^{+}$even weaker than for $\mathrm{S}$, and not significant for any of the taxonomic subsets examined (Fig. 4a-d).

For both $M A E$ and $A, \Delta^{+}$values are also not significantly related to observed species numbers (Fig. 5a; Spearman's rank correlation $\rho=0.216, P=0.459$, and Fig. 5b: $\rho=0.053, P$ $=0.871$, respectively). For $M A E$, it is evident that the taxonomic breadth of a number of ecoregions (White and Kara Seas, Hudson Complex, North and West Greenland, as well as North Labrador) is, regardless of observed species numbers, not only lower than that of the other ecoregions but also significantly smaller than the $95 \%$ probability limit of expected values of the overall taxonomic distinctness of the pan-Arctic $M A E$ fauna (Fig. 5a). This is not the case with regard to Annelida, for which all $\Delta^{+}$values cluster around the overall mean value and fall within the $95 \%$ probability limits (Fig. 5b).

\section{Station-based rarefaction curves}

From station-based rarefaction analyses (Fig. 6a, for $M A E$; Fig. 6b, for $A$ ) it is evident, regardless of the number of stations available: (i) almost all ecoregion curves show no sign of approaching an asymptote and (ii) for a given number of stations pronounced differences in species number appear to exist between ecoregions. According to the rarefaction curves, the shelves off West and North Greenland and North Labrador are characterized by highest 
diversities, the White Sea and the seas off Siberia are least diverse, and the regions north of Canada and the Chukchi Sea have an intermediate position in this diversity gradient.

The rarefied numbers of species $\mathrm{RS}_{19}$ range from $27 \pm 3$ s.d. in the White Sea to $299 \pm 25$ s.d. in North Labrador for MAE (Table 2a, Fig. 3a). For Annelida, the $\mathrm{RS}_{19}$ estimates run from $3 \pm 9$ s.d. in the East Siberian Sea to $211 \pm 23$ s.d. in West Greenland (Table 2b, Fig. 3b). Observed and rarefied species numbers are significantly positively correlated for $M A E$ (Spearman's rank correlation $\rho=0.676, P=0.008)$ and Annelida $(\rho=0.650, P=0.022)$.

\section{Estimation of expected numbers of species}

The Chao2 values used to estimate 'expected total species numbers' of MAE for each ecoregion range from $55 \pm 9$ s.d. off East Greenland to $745 \pm 47$ s.d. in the Beaufort Sea (Table 2a, Fig. 3a). These estimates exceed the observed species numbers by $11 \% \pm 4 \%$ (Chukchi Sea) to $64 \% \pm 14 \%$ (Hudson Complex). On weighted average (weighted by the ratio of the number of stations per $1000 \mathrm{~km}^{2}$ ecoregion area), our results suggest that further sampling would increase the number of $M A E$ species known to occur in the entire study area by 26 to $52 \%$ ( $39 \pm 13 \%)$, indicating that between about a fifth and a third $(28 \pm 12 \%)$ of the expected $M A E$ species pool is still unknown.

In the case of Annelida, the Chao2 values range from $24 \pm 0$ s.d. in the Eastern Bering Sea to $390 \pm 27$ s.d. off West Greenland (Table 2b, Fig. 3b). For ecoregions, which are obviously underrepresented in our data, such as the Eastern Bering and East Siberian Seas, Chao2 values are not higher than the observed species numbers; for the other ecoregions they are greater than the observed species numbers by $10 \pm 3 \%$ (Northeastern Barents Sea) to $51 \pm 20 \%$ (North Greenland). On weighted average (excluding the severely under-represented ecoregions mentioned above), Chao 2 values are 12 to $32 \%(22 \pm 10 \%)$ greater than the observed species numbers, suggesting that between about a tenth and a quarter (18 $\pm 7 \%$ ) of the annelid species actually occurring on Arctic shelves have not been reported yet.

For both $M A E$ and $A$, the rank order of Arctic shelf ecoregions remains largely the same, when considering expected instead of observed number of species. Both parameters are highly correlated (Spearman's rank correlation $\rho=0.939, P<0.0001$ for $M A E$, and $\rho=0.972$, $P<0.0001$, for $A$ ). 


\section{Faunal resemblance patterns between ecoregions}

The ecoregions also differ in terms of the taxonomic composition of their $M A E$ fauna (Fig. 7a). Two major faunal gradients are discernible: one along the $\mathrm{x}$ axis of the MDS plot between East Greenland and the Bering and Chukchi Seas and another one along the y axis ranging from the White Sea over a series of Eurasian-Arctic seas to West Greenland. This overall pattern was largely consistent when the faunal resemblances between the ecoregions are examined on the level of genera (Fig. 7b) and families (Fig. 7c), as indicated by highly significant rank correlations between the between-ecoregion similarity values computed at different taxonomic levels (RELATE Rho coefficients range between 0.915 and 0.984 , all with $P=0.001)$.

The resemblance patterns of the annelid fauna among ecoregions were analyzed for only nine ecoregions. The Laptev, East Siberian and Eastern Bering Seas were excluded, as the species numbers are too small, and thus the faunal ranges in our data are too narrow, for a meaningful comparison with the other regions that are better represented in our data. At the species level, the annelid fauna of North and East Greenland are clearly distinct from those in the remaining ecoregions, particularly as compared to the Chukchi Sea region (Fig. 7d). As in the case of the $M A E$ fauna, the annelid-based between-ecoregion resemblance patterns at different taxonomic levels (Fig. 7d,e,f) are very similar to each other (RELATE Rho coefficients fall in the range between $0.623, P=0.004$, and $0.880, P=0.001$ ).

A second-stage analysis compared the between-ecoregion patterns of different taxonomic groups (Mollusca, Arthropoda, Echinodermata, $M A E$, Annelida) at different taxonomic levels (species, genus, and family) for the nine ecoregions considered in the annelid resemblance analysis (Fig. $7 \mathrm{~g}$ ). It is evident that pattern similarities are highest among taxonomic levels within phyla. This is least so for Annelida, but even for this phylum the RELATE Rho coefficients indicate significant between-pattern correlations $(P<0.05)$. Furthermore, the MDS plot shows that the annelid between-ecoregion resemblances are most different from those of Echinodermata and Arthropoda (all RELATE Rho correlations are not significant with $P>0.05$ ) and more similar to those of Mollusca and $M A E$ (all RELATE Rho correlations are significant with $P<0.05$ ). 


\section{Discussion}

\section{Arctic-wide species inventory}

We present the first pan-Arctic inventory of the macrobenthic and megabenthic shelf species. Nevertheless, there are other large-scale studies with which some of our results can be compared. Sirenko and Piepenburg (1994) reported a total of more than 4000 zoobenthic species for the entire Eurasian Arctic, and seven years later Sirenko (2001) listed about 20\% more species, primarily because of the analysis of additional samples taken in the course of intensified research efforts such as the 10-year Russian-German Laptev Sea study (Kassens et al. 1999). Although our pan-Arctic census covers a larger area, namely both the eastern and the western Arctic, the total number of species in our data (2636) is smaller than the figure reported by Sirenko (2001), whose inventory of the "free-living invertebrates of Eurasian Arctic seas and adjacent deep waters" comprises a total of 4814 species, 4357 of which can be regarded as being benthic.

In general, it is acknowledged that all diversity inventories are potentially biased to some degree by a host of methodological factors, e.g., differences in sampling intensity, taxonomic scope and spatial scales covered, and therefore any large-scale comparisons of species diversity are rather problematic (Hurlbert 1971). In this case, the taxonomic coverage of our inventory must be taken into account when comparing the results to other studies of Arctic diversity. Sirenko (2001), for instance, considered 56 invertebrate higher taxa at different levels (including 24 phyla) in his census. Our analyses, however, were confined to macrobenthic and megabenthic species of shelf regions and, therefore, a range of higher taxa included in his lists (Foraminifera, Radiolaria, Ciliophora, Scyphozoa, Ctenophora, Nematoda, Rotifera, Tardigrada, Acari, Cladocera, Calanoida, Harpacticoida, Euphausiacea, Chaetognatha, and Appendicularia) are not considered in our analyses. If restricted to the 38 higher taxa from 16 phyla, usually regarded to encompass primarily macro- or megabenthic species, Sirenko's (2001) list contains a total of 3054 species, including 485 Mollusca, 890 Arthropoda, 150 Echinodermata (1525 species combined), and 522 Annelida. These figures are quite close to our numbers of observed species, $16 \%$ higher for the total number of species and between $24 \%$ higher and 34\% lower for the number of species of the four major phyla. Overall, this comparison suggests that our inventory provides comparable accounts of the major phyla Mollusca, Arthropoda, Annelida and Echinodermata, whereas the minor phyla appear to be less well represented in our data, as indicated by the particularly small species numbers of some taxa such as, e.g., sponges. The poor representation of these taxa is likely 
related to several reasons, e.g., the poor taxonomic emphasis and training for those groups in most western ecologists and bias in the sampling data sets such that their preferred hardbottom habitats were poorly sampled relative to soft-bottom sites.

In an approach similar to ours, Bluhm et al. (this volume) assessed the biodiversity of the Arctic deep sea, i.e., the Arctic regions beyond the shelf break (> $500 \mathrm{~m}$ depth). Their panArctic deep-sea database comprises 725 macro- and megabenthic species, a large part of which (444 species, equivalent to $61 \%$ of their total species number) have been reported from the Arctic shelves covered in our study. This finding suggests that many known Arctic deepsea species are actually eurybathic animals occurring over a wide water depth range. It should be noted, however, that for the deep sea the difference between the number of known species and those actually occurring there is very likely much larger than for the shelf regions (Gray et al. 1997) and, hence, this conclusion is only preliminary and could be disproven by further investigations.

Our estimates of the expected numbers of species are confined to the ecoregion scale and to the major, reasonably well represented phyla Mollusca, Arthropoda, Echinodermata and Annelida. Based on certain assumptions, however, we can also provide a gross estimate of expected species for the entire study area and the whole macro- and megabenthic fauna. Our analyses of species diversity in the ecoregions suggest that on average the expected numbers of species exceed the observed numbers of mollusk, arthropod and echinoderm species by $39 \pm 13 \%$ based on the Chao 2 estimate. Extrapolated to the entire study area, from which a total of 1467 species are included in our database, this would mean that the expected number of $M A E$ is about $2040 \pm 190$. In the case of annelids, an analogue approximation approach, based on an across-ecoregion mean ratio of expected to observed species of $1.22 \pm 0.1$ and a total number of 668 observed species, yields a total of $816 \pm 71$ expected annelid species. Together, the expected species numbers of the four major phyla total between 2596 and 3116 (2856 \pm 260$)$ species. In the comprehensive inventory of Sirenko (2001), Mollusca, Annelida, Arthropoda and Echinodermata account together for about two-thirds of the entire macro- and megabenthic fauna. We regard Sirenko's inventory to be more realistic than our data in terms of the overall species shares of the entire range of phyla because compiled by taxonomic experts only. Applying the two-thirds ratio to our pan-Arctic estimates, we conclude that about 3894 to 4674 (4284 \pm 390$)$ macro- and megabenthic species can be expected to inhabit the Arctic shelf regions. 
Due to several biases (see methodological considerations below), our figures of observed and expected numbers of species are without doubt only gross and conservative approximations of the numbers of species occurring in Arctic shelf seas. Archambault et al. (submitted) provided evidence of unusually high numbers of known species in Arctic regions compared to Atlantic waters in a review of the marine biodiversity of the three oceans around Canada, despite pronouncedly lower sampling effort levels. This conclusion casts doubts on the general validity of the commonly assumed latitudinal diversity decline in species diversity (Gray et al. 1997). Furthermore, published species numbers are very likely underestimating the real diversity, since numerous currently-known species, that are identified based on morphological traits, are actually representing a set of genetically distinct cryptic species. For instance, DNA barcoding efforts showed recently that this is the case for at least one quarter of the polychaete species (morphospecies) known from Canadian waters (Radulovici et al. 2010; C. Carr, pers. comm.).

Gutt et al. (2004) presented gross estimates of how many macrobenthic species might inhabit the shelf of the Weddell Sea (2100 to 10,500, excluding the so-called "shallow fauna" species, in an area of $7000 \mathrm{~km}^{2}$ ) as well as the entire Antarctic shelf (9000 to 14,000 species in an area of 2,200,000 $\mathrm{km}^{2}$ ). The latter area is only about a quarter of the total extent of the Arctic shelves considered in our inventory (see Table 1)). Their estimates are not entirely comparable to ours, since they were not based on the evaluation of a great number of faunal lists from a wide variety of regions. Instead, their estimate only consisted of the analysis of 16 trawl catches in the Weddell Sea (yielding 820 species in total), a suite of non-parametric rarefaction-based approaches (including computation of Chao2 values), and assumptions about the species shares of taxa not considered in the survey and scaling their limited survey up to the entire Antarctic shelf. Considering the smaller area of the Antarctic shelves, a comparison of Gutt et al. (2004) and our estimates suggests that the number of benthic shelf species in the Antarctic appears to be slightly higher than in the Arctic. The difference between the two faunas is, however, not as pronounced as assumed two or three decades ago (Knox and Lowry 1977; Dayton 1990); it appears to be at a factor of only about two rather than an order of magnitude. Our results provide further evidence for the notion that, on a global scale and compared to other large marine ecosystems, such as the entire deep sea (500,000 species, May 1992; 10,000,000 species; Grassle and Maciolek 1992) and all tropical coral reefs (up to 670,000 species; Reaka-Kudla 1997), both Arctic and Antarctic shelves are characterized by intermediate macro- and megabenthic species numbers (Gutt et al. 2004; Piepenburg 2005). 


\section{Regional patterns}

Sirenko (2001) also demonstrated that known benthic diversity varies broadly (by a factor of three) among Eurasian Arctic seas from the Barents Sea to the East Siberian Sea, suggesting a clear eastward decline in species numbers. Our macro- and megabenthic inventory largely corroborates Sirenko's (2001) findings, which confirmed those values reported by Zenkevitch (1963). Our analysis also explicitly shows that the trend of decreasing species numbers from the Barents to the East Siberian Sea in the Eurasian Arctic may not only reflect a zoogeographic pattern, caused by differences in climate, geographic position and immigration rates of Atlantic and Pacific immigrants (Zenkevitch 1963, Carmack and Wassmann 2006), but also the pronounced differences in sampling effort among regions. For instance, the Barents Sea is still much more thoroughly studied than the Laptev or East Siberian Seas, despite recently intensified sampling efforts in the latter regions. We found a quite high, statistically significant correlation between observed species numbers, which are known to be very dependent on sampling effort, and rarefied species numbers, which are much less dependent on sampling effort. This indicates that, on a large scale, the between-ecoregion differences in observed and rarified species numbers reflect a very similar pattern of diversity disparities among ecoregions. There are, however, also notable exceptions. Such is the case for the particularly well-studied Barents Sea ( 1800 samples), which not surprisingly ranks first in terms of observed species numbers (595 mollusk, arthropod and echinoderm species, 322 annelid species) but only ninth in case of both $M A E$ and $A$ in terms of rarefied species numbers (62 \pm 26 s.d. and $29 \pm 36$ s.d., respectively). Moreover, rarefied species numbers are not significantly higher in the Barents Sea than in the seas off Siberia. These findings highlight the necessity of accounting for differences in sampling effort when comparing species diversity parameters. Based on our data we cannot confirm that the Barents Sea is truly richer in benthic species than the more eastern shelf regions off Siberia. However, if a difference exists, it may, in fact, result from a higher riverine freshwater inflow and thus higher seasonal salinity fluctuations influencing the Siberian shelf systems (Carmack et al. 2006).

Overall, the distribution of species numbers and species distinctness across ecoregions is quite similar in our data for $M A E$ and $A$, indicating that diversity differences between ecoregions are consistent across these two faunal subsets. Furthermore, the various diversity measures we used, observed and rarefied species numbers, as well as station-based rarefaction curves, provided largely comparable pictures of the potential diversity differences among the 
Arctic shelf regions (while inconsistencies can be explained by the high variability of the parameter estimates and the curves' trajectories). The shelves off Greenland (excluding East Greenland, which is severely under-represented in our data) and North Labrador are characterized by highest diversities, whereas the seas off Siberia are poorest (or most underrepresented in our data), and the species numbers of the regions north of Canada and the Chukchi Sea are intermediate.

With regard to the between-ecoregion resemblance pattern in terms of the composition of the mollusk, arthropod and echinoderm fauna combined and annelids only (Fig. 7a-f), there are apparently two major faunal gradients. The first one along the horizontal axis of the MDS plots, between East Greenland on the one side and the Chukchi and Bering Seas on the other side, largely reflects a gross eastern Arctic-western Arctic grade with regard to biogeographic affiliation. It is most pronounced at the species level and less discernible at higher taxonomic levels, although the patterns at the different levels are largely comparable, as the high RELATE correlation coefficients indicate. The second gradient along the vertical axis of the MDS plots, ranging for $M A E$ from the White Sea over a series of Eurasian-Arctic seas to West Greenland, is more difficult to interpret. It most likely reflects a mixture of different influences (geographic location, ice conditions, estuarine impact), which are known to shape the environmental conditions of the ecoregions (Carmack et al. 2006) and can thus be assumed to drive the diversity and composition of their faunas (Carmack and Wassmann 2006).

\section{Methodological considerations}

Our study is the first comprehensive circumpolar effort to assess the 'state-of-the-art' knowledge on the diversity patterns of the Arctic shelf benthos. It should be noted, however, that the numbers of species reported here represent conservative estimates because our inventory is incomplete with regard to (i) the species already known from the Arctic but not included in our data, and (ii) all species expected to occur in Arctic shelf regions but not sampled yet.

The first deficiency is evident even at the coarsest spatial level of our study (the entirety of all 19 Arctic shelf ecoregions). Only a subset of the entire taxonomic range is included in our inventory. The census comprehensiveness strongly varies among taxonomic groups, and some higher taxa are especially poorly covered, such as for instance Porifera. The number of sponge species known from the shelves and slopes off Greenland totals 210 and for the entire 
Arctic it is expected to be 250 to 300 species (Tendal, personal communication). The small number of species in our data (35) clearly demonstrates that Porifera are particularly underrepresented (by $\sim 80 \%$ ) in our inventory. Other taxa are better represented than sponges but even in these cases the overall number of species in our data does not represent the actual number of known species from Arctic shelf regions. In the case of Bryozoa, for instance, the total number of species in our data set adds up to 205, whereas more than 350 species are actually known to inhabit Arctic shelves (Kuklinski, personal communication) and thus our census underestimates the actual known species number of Bryozoa by $40 \%$. Moreover, it should be noted that some higher taxa, primarily those encompassing mostly small, less prominent and difficult-to-identify animals, such as Hydrozoa or Nemertina, are not as comprehensively investigated as Polychaeta, Bivalvia, Crustacea, and Echinodermata.

The caveats resulting from incomplete and unevenly distributed data are even more pronounced at the level of single ecoregions. From one ecoregion (\#10 - High Arctic Archipelago), we do not have any record at all in our data set; from four others (\#2 - North Iceland, \#5 - Northern Grand Banks - Southern Labrador, \#7 - Baffin Bay, and \#9 - Lancaster Sound) our data are so scarce that they could not be included in the comparative betweenecoregion analyses (Table 1), and the remaining 14 ecoregions considered in the comparative analyses differ widely in the number of stations in our data, with most to be regarded as being either truly under-sampled (e.g., East Greenland) or actually well-sampled but severely underrepresented in our database (e.g., Eastern Bering Sea).

In our data, there is only a weak positive trend between the number of stations (used as an approximation of sampling effort) and the number of species recorded in the ecoregions (Fig. $4 a, c)$. Nevertheless, these non-significant relationships were clearly stronger than those between number of stations and taxonomic distinctness $\left(\Delta^{+}\right)$, indicating that (i) the species inventory is incomplete for most ecoregions and due caution is advised when comparing species diversity among regions, and (ii) taxonomic distinctness is independent from sampling effort and thus better suited for viable between-ecoregion comparisons than observed species numbers. Furthermore, the lack of a relation between species numbers (S) and species distinctness $\left(\Delta^{+}\right)$supports the notion that the latter quantifies an additional biodiversity trait that is not connected with pure number of species (Clarke and Warwick 2001a).

The taxonomic distinctness of the $M A E$ fauna in a number of ecoregions (White and Kara Seas, Hudson Complex, North and West Greenland, North Labrador) is not only lower than 
that in other ecoregions but also significantly lower than the overall taxonomic distinctness of the pan-Arctic MAE fauna (Fig. 5a). There are two possible explanations for this pattern. It may either indicate a truly reduced biodiversity (in terms of taxonomic breadth) in the respective ecoregions or it is to a great extent caused by the rather narrow taxonomic range in the faunal investigations of the respective ecoregions. The latter methodological constraint is independent of the number of samples taken (and, hence, overall number of species recorded) and noticeable even in presumably well-studied taxa, such as mollusks, arthropods and echinoderms. The lack of such a pattern for Annelida (Fig. 5b) suggests, in terms of the taxonomic breadth of the annelid fauna, that there is no significant difference between the ecoregions considered in our analysis and/or that these ecoregions were studied with comparable intensity.

Station-based rarefaction showed more clearly the influence of sampling effort variation on the assessment of species diversity than the direct relationship between sampling effort and observed species number. Therefore, we used species rarefaction curves for each ecoregion to compare species numbers among ecoregions. The curves also clearly indicate that the numbers of observed species in the data severely under-estimate potential total numbers of species occurring in the region, even in case of relatively well sampled regions, such as the Barents Sea, and well studied taxa, such as mollusks, arthropods, and echinoderms (Fig. 6a), or annelids (Fig. 6b).

The difference between known and expected species numbers represents the second and more obvious type of census incompleteness. The number of species known from an area is largely dependent on the number of samples taken, and it is always lower than the total expected number of species occurring in the area unless a very large number of samples are analyzed. It is only then that rare species are included in the inventory. There are a number of approaches that can be used to estimate the expected species numbers occurring in an area (Colwell and Coddington 1994). Here, we computed Chao2 estimates for each ecoregion (Table 2, Fig. 3). These estimates are based on the number of 'rare' species, i.e., those occurring only at one or two stations in an ecoregion. Therefore, it should be noted again that the concept of a 'station' varies among ecoregions: in some cases (e.g., North Labrador) it includes many species from various phyla and represents quite a comprehensive inventory of the whole macro- and megabenthic community at a location; in others (e.g., most stations from the Barents Sea) it is a record of just a single or a few species. This variation in the type of 'station' influences the computation of Chao2 values. Therefore, our values have to be 
regarded as gross and rather conservative estimates. In our comparisons between ecoregions the analyses do not necessarily reflect true diversity contrasts and differences in faunal composition. To a certain degree, the observed patterns are also caused by methodological differences in the taxonomic range/breadth of a typical 'station' in the ecoregion data.

The distinct position of the comparatively station-poor ecoregion East Greenland in the MDS plots, used to illustrate the large-scale spatial faunal patterns (Fig. 7a-f), indicates that differential sampling intensity (and, hence, method-based differences in species number) is a confounding factor affecting the between-region resemblance computations and the observed differences in faunal composition.

Finally, the potential influence of temporal dynamics in species composition has to be considered. The samples included in our database were collected over a long period of time (1955-2009). Temporal gaps in our data and uneven distribution in time may have confounded our spatial analyses. The potential bias due to uncontrolled temporal variability is minimized, however, by (i) analyzing presence/absence data only (as these data are not as sensitive to change as species abundance or biomass), (ii) applying a rather coarse spatial data aggregation approach, e.g., by grouping the data in ecoregions that represent 'natural geographical units', and (iii) using a hierarchical taxonomic aggregation approach for comparative between-ecoregion analyses. Furthermore, Cusson et al. (2007) showed that the temporal variability (in benthic abundances) is of the same order as spatial variability at rather small scales (few km) only and suggested that larger, Arctic-wide or ecoregion-wide patterns may be less affected by changes in time.

\section{Perspectives for future work}

There are several possible avenues for future studies extending and refining our inventory, which only represents a preliminary account of Arctic shelf diversity. First and foremost, the issue of the incompleteness of our database has to be resolved. On the one hand, additional field sampling is needed, particularly in hitherto poorly investigated regions such as the High Arctic Archipelago. In general, novel field collections should be designed in such a way that they cover environmental and geographic gradients and will thus help determining large-scale cross-ecoregion patterns. Furthermore, our study also has clearly shown that a pan-Arctic effort to regularly apply a suite of standardized sampling approaches and methods in future field studies, in order to adequately sample the full range of taxa and habitats and to achieve consistent and highly comparable species distribution data, should be a high priority. 
On the other hand, and maybe even more pressing, further data mining work is required. Without doubt, there are numerous historic data sets available (in zoological museums, technical reports, etc.), which are not yet included in our pan-Arctic database but could help in not only extending the geographic range of our current study but also enhancing its taxonomic breadth, particularly for regions that are currently poorly represented in our data. This data scarcity does not only apply to the number of stations, and thus to species number, but also to the taxonomic range covered, which for some regions, such as the Kara Sea, was very narrow in our data. Further examples are actually well-sampled but in our data underrepresented regions, such as the Eastern Bering Sea (from where comprehensive macrofaunal data are not included in our inventory, e.g., from the southeastern Bering Sea, comprising 389 species (Feder et al. 1980; Haflinger 1981), and the northeastern Bering Sea, comprising 487 taxa (Feder et al. 1982)), or the Lancaster Sound, Eclipse Sound and northern and central Baffin Bay (which were investigated by Thomson (1982) with 204 grab and diver-operated airlift samples). Efforts to discover, retrieve, compile, validate and share such historic data sets should have high priority in future projects. In addition, we strongly endorse ongoing and future taxonomic studies based on molecular markers (Mincks Hardy et al. this issue; Gradinger et al. 2010), which will surely lead to increased species numbers in most taxa and have thus significant impacts on species diversity assessments. The Arctic Ocean Diversity (ArcOD) initiative would provide an appropriate common framework for addressing these issues.

Given that the issues of gathering additional data and expanded taxonomic work are properly addressed, more advanced analyses will be feasible, as for example by applying a nested approach of geographical data aggregation (e.g., by consecutively larger quadrates of $100 \mathrm{~km}^{2}, 1000 \mathrm{~km}^{2}$ and $10,000 \mathrm{~km}^{2}$ ). By avoiding the caveats resulting from the inconsistent meaning of the term 'station' in our study, this would allow for a meaningful study of distribution patters at smaller ('local' and 'sub-regional') spatial scales than that of ecoregions $\left(100,000-1,000,000 \mathrm{~km}^{2}\right)$ applied in this paper. Furthermore, it would render explicit analyses for identifying potential drivers and processes determining the observed species distribution and diversity patterns possible.

\section{Conclusions}

We provide a first pan-Arctic assessment of the macro-and megabenthic biodiversity of Arctic shelves. Based on an unprecedentedly thorough compilation of species distribution data from almost all Arctic marine ecoregions, we were able to present a comparative view of the 
current knowledge on benthic diversity patterns on a regional and Arctic-wide scale and give conservative estimates of expected total number of benthic species for each ecoregion as well as for the entire Arctic shelf. Our results provide further evidence that Arctic shelves are not particularly impoverished, confuting a common paradigm on low Arctic diversity, but are similar in overall species numbers to the Antarctic shelf, with both polar biomes characterized, on a global scale, by intermediate values.

Our study also documents that despite recent sampling efforts in previously poorly studied Arctic areas the quality and quantity of available information still broadly varies among both regions and taxa. This imbalance in knowledge has the potential of severely confounding both comparative analyses and predictive estimates of overall biodiversity. Due to the difficulties generally encountered in biogeographic and species/taxa synopses of a study area as large as the Arctic, the data presented here are still incomplete and our census is thus only preliminary. Efforts to recover further historic data sets will be invaluable to future inventories of benthic fauna in the Arctic.

We are confident that our inventory will lead the way for future investigations extending and refining our findings which are essential to understand and evaluate possible changes in the biodiversity of the still relatively pristine but increasingly threatened marine ecosystems of the Arctic.

\section{Acknowledgements}

We'd like to thank all the people who contributed to this study with helping in the field studies, identifying species, as well as providing data and advice. Special thanks go to C. Nozère (Rimouski) who helped in homogenizing the database and matching the scientific names, as well as to Julian Gutt (Bremerhaven), Russ Hopcroft (Fairbanks) and two anonymous reviewers whose comments greatly improved our manuscript.

We also acknowledge the financial support of a wide variety of national and international organizations, which provided funds for the original field research that has generated the data our synthesis is based on: Canadian Museum of Nature, Fisheries and Oceans Canada, Natural Sciences and Engineering Research Council of Canada, ArcticNet, United States National Science Foundation, United States Mineral Management Service, National Oceanic and Atmospheric Administration, Russian Academy of Sciences, Research Council of 
Norway, Commission for Scientific Research in Greenland, German Research Foundation, German Federal Ministry of Research and Technology. The synthesis effort itself, resulting in this paper, was supported by the Alfred P. Sloan Foundation.

This publication is part of the Census of Marine Life's Arctic Ocean Diversity project synthesis and was originally presented at the Arctic Frontiers Conference in Tromsø, January 2010. The support and initiative of ARCTOS and Arctic Frontiers are gratefully acknowledged. The paper is also a contribution to the Canadian Healthy Oceans Network.

\section{References}

Anonymous (1978) Bundinvertebrater på Store og Lille Hellefiskebanke og i Holsteinsborgdybet. Technical report from Marin ID (in Danish)

Archambault P, Snelgrove PVR, Fisher JAD, Gagnon J-M, Garbary DJ, Harvey M, Kenchington E, Lesage V, Levesque M, Lovejoy C, Mackas D, McKindsey CW, Nelson J, Pepin P, Piché L, Poulin M (subm) From sea to sea: Canada's three oceans of biodiversity. PlosOne

Arctic Monitoring and Assessment Programme (1998) AMAP Assessment Report: Arctic Pollution Issues. Arctic Monitoring and Assessment Programme (AMAP), Oslo, Norway

Atkinson EG, Wacasey JW (1989a) Benthic invertebrates collected from Hudson Bay, Canada, 1953 to 1965. Can Data Rep Fish Aquat Sci 744

Atkinson EG, Wacasey JW (1989b) Benthic invertebrates collected from the western Canadian Arctic, 1951 to 1985. Can Data Rep Fish Aquat Sci 745

Bluhm BA, Ambrose Jr WG, Bergmann M, Clough LM, Gebruk AV, Hasemann C, Iken K, Klages M, MacDonald IR, Renaud PE, Schewe I, Soltwedel T, Włodarska-Kowalczuk M (this issue) Biodiversity of the Arctic deep sea benthos. Mar Biodiv

Bluhm BA, Iken K, Mincks Hardy S, Sirenko BI, Holladay BA (2009) Community structure of epibenthic megafauna in the Chukchi Sea. Aquat Biol 7: 269-293 
Bluhm BA, MacDonald IR, Debenham C, Iken K (2005) Macro- and megabenthic communities in the high Arctic Canada Basin: initial findings. Polar Biol 28:218-231

Bluhm BA, Piepenburg D, Juterzenka K von (1998) Distribution, standing stock, growth, mortality and production of Strongylocentrotus pallidus (Echinodermata: Echinoidea) in the northern Barents Sea. Polar Biol 20:325-334

Brandt A, Vassilenko S, Piepenburg D, Thurston M (1996) The species composition of the peracarid fauna (Crustacea, Malacostraca) of the Northeast Water Polynya (Greenland). Meddr Grønland Biosci 44:1-30

Carey A (1981) The distribution, abundance, diversity and productivity of the western Beaufort Sea benthos. Environm Assessm Alaskan Cont Shelf 2:1-27

Carmack E, Barber D, Christensen J., Macdonald R, Rudels B, Sakshaug E (2006) Climate variability and physical forcing of the food webs and the carbon budget on panarctic shelves. Prog Oceanogr 71:145-181

Carmack E, Wassmann P (2006) Food webs and physical-biological coupling on pan-Arctic shelves: comprehensive perspectives, unifying concepts and future research. Prog Oceanogr 71:449-480

Carroll ML, Denisenko SG, Renaud PE, Ambrose Jr WG (2008) Benthic infauna of the seasonally ice-covered western Barents Sea: Patterns and relationships to environmental forcing. Deep Sea Res II 55:2340-2351, doi:10.1016/j.dsr2.2008.05.022

Chao A (1987) Estimating the population size for capture-recapture data with unequal catchability. Biometrics 43:783-791

Clarke A, Crame JA (1992) The southern ocean benthic fauna and climate change: a historical perspective. Phil Trans R Soc Lond 338:299-30

Clarke KR, Gorley RN (2006) PRIMER v6: User Manual/Tutorial. PRIMER-E, Plymouth

Clarke KR, Warwick RM (2001a) A further biodiversity index applicable to species lists: variation in taxonomic distinctness. Mar Ecol Prog Ser 216:265-278

Clarke KR, Warwick RM (2001b) Change in marine communities: an approach in statistical analysis and interpretation. 2n edition. PRIMER-E, Plymouth 
Cochrane SKJ, Denisenko SG, Renaud PE, Emblow CE, Ambrose Jr WG, Ellingsen IH, Skarðhamar J (2009) Benthic macrofauna and productivity regimes in the Barents Sea Ecological implications in a changing Arctic. J Sea Res 61:222-233

Colwell RK, Coddington JA (1994) Estimating terrestrial biodiversity through extrapolation. Phil Trans R Soc Lond B 345:101-118

Conlan KE, Aitken A, Hendrycks E, Melling H, McClelland C (2008) Distribution patterns of Canadian Beaufort Shelf macrobenthos. J Mar Syst 74:864-886

Conlan KE, Kvitek RG (2005) Recolonization of soft-sediment ice scours on an exposed Arctic coast. Mar Ecol Prog Ser 286:21-42

Curtis MA (1975) The marine benthos of Arctic and Sub-arctic continental shelves. A review of regional studies and their general results. Polar Rec 17:595-626

Cusson M, Archambault P, Aitken A (2007) Biodiversity of benthic assemblages of the Arctic continental shelf: historical data from Canada. Mar Ecol Prog Ser 331:291-304

Dayton PK (1990) Polar Benthos. In: Smith Jr WO (ed) Polar Oceanography, Part B: Chemistry, biology, and geology. Academic Press, San Diego, pp 631-685

Denisenko SG, Denisenko NV, Lehtonen KK, Andersin A-B, Laine AO (2003) Macrozoobenthos of the Pechora Sea (SE Barents Sea): community structure and spatial distribution in relation to environmental conditions in relation to environmental conditions. Mar Ecol Prog Ser 258:109-123

Feder HM, Day RH, Jewett SC, McCumby K, McGee S, Schonberg SV (1982) Infauna of the Northeastern Bering and Chukchi Seas. Final Report Outer Continental Shelf Environmental Assessment Program, Research Unit 5, 120 pp

Feder HM, Haflinger K, Hoberg M, McDonald J (1980) The infaunal invertebrates of the southeastern Bering Sea. Final Report to NOAA, R.U. No 5, 399 pp

Feder HM, Jewett SC, Blanchard A (2005) Southeastern Chukchi Sea (Alaska) epibenthos. Polar Biol 28:402-421

Feder HM, Jewett SC, Blanchard A (2007) Southeastern Chukchi Sea (Alaska) macrobenthos. Polar Biol 30:261-275 
Feder HM, Naidu AS, Jewett SC (1994) The northeastern Chukchi Sea: benthosenvironmental interactions. Mar Ecol Prog Ser 111:171-190

Gage JD, Tyler PA (1991) Deep-sea biology: a natural history of organisms at the deep-sea floor. Cambridge University Press, Cambridge

Gotelli NJ, Colwell RK (2001) Quantifying biodiversity: procedures and pitfalls in the measurement and comparison of species richness. Ecol Lett 4:379-391

Gradinger RR, Bluhm BA, Hopcroft RR, Gebruk AV, Kosobokova KN, Sirenko BI, Węsławski JM (2010) Chapter 10: Marine life in the Arctic. In: MacIntyre A (ed) The census of marine life: Diversity, distribution, and abundance. Wiley-Blackwell, Hoboken

Grassle JF, Maciolek NJ (1992) Deep-sea species richness: regional and local diversity estimates from quantitative bottom samples. Am Nat 139:313-341

Gray JS, Poore GCB, Ugland KI, Wilson RS, Olsgard F, et al (1997) Coastal and deep-sea benthic diversities compared. Mar Ecol Prog Ser 159:97-103

Grebmeier JM, Barry JP (1991) The influence of oceanographic processes on pelagic-benthic coupling in polar regions: a benthic perspective. J Mar Syst 2:495-518

Grebmeier JM, Cooper LW, Feder HM, Sirenko BI (2006) Ecosystem dynamics of the Pacific-influenced Northern Bering and Chukchi Seas in the Amerasian Arctic. Prog Oceanogr 71:331-361

Gutt J, Sirenko BI, Smirnov IS, Arntz WE (2004) How many macrozoobenthic species might inhabit the Antarctic shelf? Antarct Sci 16:11-16

Haflinger K (1981) A survey of benthic faunal communities of the southeastern Bering Sea. In: Hood DW, Calder J (eds) The Eastern Bering Shelf: Oceanography and Resources. Vol. II. U. S. Dept. of Commerce:1091-1103

Hempel G (1985) Antarctic marine food webs. In: Siegfried WR, Condy PR, Laws RM (eds) Antarctic nutrient cycles and food webs. Springer, Berlin, pp 266-270 
Hopky GE, Lawrence MJ, Chiperzak DB (1994) NOGAP B2: data on the meio and macrobenthos, and related bottom sediment from Tuktoyaktuk Harbour and Mason Bay, NT, March 1985 to 1988. Can Data Rep Fish Aquat. Sci 939:1-297

Hurlbert SH (1971) The non-concept of species diversity: a critique and alternative parameters. Ecology 52:577-586

International Hydrographic Organization (2001) Limits of oceans and seas. 4th edition. Rep S-23, Monaco

Jakobsson M (2002) Hypsometry and volume of the Arctic Ocean and its constituent seas. Geochem Geophys Geosys 3:p1-18. doi: 10.1029/2001GC000302

Kassens H, Bauch HA, Dmitrenko IA, Eicken H, Hubberten H-W, Melles M, Thiede J, Timokhov LA (1999) Land-Ocean Systems in the Siberian Arctic: Dynamics and History. Springer, Berlin

Kendall MA, Aschan M (1993) Latitudinal gradients in the structure of macrobenthic communities: a comparison of Arctic, temperate and tropical sites. J Exp Mar Biol Ecol 172:157-169

Knox GA, Lowry JK (1977) A comparison between the benthos of the Southern Ocean and the North Polar Ocean, with special reference to the Amphipoda and the Polychaeta. In: Dunbar MJ (ed) Polar Oceans. Arctic Institute of North America, Calgary, pp 423-462

Lalande C (2003) Composition et structure de la communauté benthique et quantification de la bioturbation dans la polynie des Eaux du Nord. MSc Thesis, Université du Québec à Rimouski, Canada

MacGinitie GE (1955) Distribution and ecology of the invertebrates of Point Barrow, Alaska. Smithsonian Institution Collections 128:1-201

MacLaren MAREX (1978) Report on marine benthic invertebrates of the southern Davis Strait and Ungava Bay for Imperial Oil Limited, Aquitaine Company of Canada Limited and Canada Cities Service Limited. MacLaren MAREX, Dartmouth

May RM (1992) Bottoms up for the oceans. Nature 357:278-279 
Mincks Hardy S, Carr CM, Hardman M, Steinke D, Corstorphine E, Mah C (this issue)

Biodiversity and phylogeography of Arctic marine fauna: Insights from molecular tools. Mar Biodiv

Piepenburg D (1988) Zur Zusammensetzung der Bodenfauna in der westlichen Fram-Straße. Ber Polarforsch 52:1-118

Piepenburg D (2005) Recent research on Arctic benthos: Common notions need to be revised. Polar Biol 28:733-755

Piepenburg D, Chernova NV, von Dorrien CF, Gutt J, Neyelov AV, Rachor E, Saldanha L, Schmid MK (1996) Megabenthic communities in the waters around Svalbard. Polar Biol 16:431-446

Radulovici AE, Archambault P, Dufresne D (2010) DNA barcodes for marine biodiversity: moving fast forward? Diversity 2:450-472. doi:10.3390/d20x000x

Reaka-Kudla ML (1997) The global diversity of coral reefs: a comparison with rain forests. In: Reaka-Kudla ML, Wilson DE, Wilson EO (eds) Biodiversity II: understanding and protecting our biological resources. National Academy of Sciences, Washington, DC, pp 83-108

Renaud PE, Webb TJ, Bjorgesaeter A, Karakassis I, Kedra M, Kendall MA, Labrune C, Lampadariou N, Somerfield PJ, Wlodarska-Kowalczuk M, Berghe EV, Claus S, Aleffi IF, Amouroux JM, Bryne KH, Cochrane SJ, Dahle S, Degraer S, Denisenko SG, Deprez T, Dounas C, Fleischer D, Gil J, Gremare A, Janas U, Mackie ASY, Palerud R, Rumohr H, Sarda R, Speybroeck J, Taboada S, Van Hoey G, Węsławski JM, Whomersley P, Zettler ML (2009) Continental-scale patterns in benthic invertebrate diversity: insights from the MacroBen database. Mar Ecol Prog Ser 382:239-252

Schnack K (1998) Besiedlungsmuster der benthischen Makrofauna auf dem ostgrönländischen Kontinentalhang. Doctoral thesis. Ber Polarforsch 294:1-124

Sejr MK, Jensen KT, Rysgaard S (2000) Macrozoobenthos community structure in a higharctic East Greenland fjord. Polar Biol 23:792-801 
Sejr MK, Włodarska-Kowalczuk M, Joanna Legeżyńska L, Blicher ME (2010) Macrobenthic species composition and diversity in the Godthaabsfjord system, SW Greenland. Polar Biol 33:421-431. doi: 10.1007/s00300-009-0717-z

Sirenko BI (2001) List of species of free-living invertebrates of Eurasian Arctic seas and adjacent deep waters. Russian Academy of Sciences, Zoological Institute, St Petersburg, Explorations of the fauna of the seas 51(59), $131 \mathrm{pp}$

Sirenko BI (2004) Fauna i ekosistemy morya Laptevykh i sopredel'nykh glubokovodnykh uchastkov Arkticheskogo basseina (Fauna and ecosystems of the Laptev Sea and the adjacent deep-water areas of the Arctic Basin), Issledovaniya fauny morei (Exploration of the Fauna of the Seas) volume 54 (62), parts 1-2

Sirenko BI (2009) Main differences in macrobenthos and benthic communities of the Arctic and Antarctic, as illustrated by comparison of the Laptev and Weddell Sea faunas. Russ J Mar Biol 35:445-453

Sirenko BI, Piepenburg D (1994) Current knowledge on biodiversity and benthic zonation patterns of Eurasian Arctic shelf seas, with special reference to the Laptev Sea. In: Kassens H, Hubberten H-W, Pryamikov SM, Stein R (eds) Russian-German cooperation in the Siberian shelf seas: Geo-system Laptev-Sea. Ber Polarforsch 144:6977

Somerfield PJ, Clarke KR (1995) Taxonomic levels, in marine community studies, revisited. Mar Ecol Prog Ser 127:113-119

Spalding MD, Fox HE, Allen GR, Davidson N, Ferdaña ZA, Finlayson M, Halpern BS, Jorge MA, Lombana A, Lourie SA, Martin KD, McManus E, Molnar J, Recchia CA, Robertson J (2007) Marine Ecoregions of the World: A Bioregionalization of Coastal and Shelf Areas. BioScience 57:573-583

Starmans A, Gutt A, Arntz WE (1993) Mega-epibenthic communities in Arctic and Antarctic shelf areas. Mar Biol 135:1432-1793

Steffens M, Piepenburg D, Schmid MK (2006) Distribution and structure of macrobenthic fauna in the eastern Laptev Sea in relation to environmental factors. Polar Biol 29:83784 
Thomson DH (1982) Marine benthos in the Eastern Canadian High Arctic: Multivariate analyses of standing crop and community structure. Arctic 35:61-74

Vandepitte L, Vanhoorne B, Kraberg A, Anisimova N, Antoniadou C, Araújo R, Bartsch I, Beker B, Benedetti-Cecchi L, Bertocci I, Cochrane S, Cooper K, Craeymeersch J, Christou E, Crisp D, Dahle S, de Boissier M, de Kluijver M, Denisenko S, De Vito D, Duineveld G, Escaravage V, Fleischer D, Fraschetti S, Giangrande A, Heip C, Hummel H, Janas U, Karez R, Kedra M, Kingston P, Kuhlenkamp R, Libes M, Martens P, Mees J, Mieszkowska N, Mudrak S, Munda I, Orfanidis S, Orlando-Bonaca M, Palerud R, Rachor E, Reichert K, Rumohr H, Schiedek D, Schubert P, Sistermans W, Pinto I, Southward A, Terlizzi A, Tsiaga E, van Beusekom J, Vanden Berghe E, Warzocha J, Wasmund N, Weslawski J, Widdicombe C, Włodarska-Kowalczuk M, Zettler M (2010) Data integration for European marine biodiversity research: creating a database on benthos and plankton to study large-scale patterns and long-term changes. Hydrobiologia: doi:10.1007/s10750-010-0108-z

Wacasey JW, Atkinson EG, Kinlough L (1976) Zoobenthos data from James Bay, 1959, 1974. Fish Mar Serv Res Dev Tech Rep 661

Wacasey JW, Atkinson EG, Derick L, Weinstein A (1977) Zoobenthos data from the southern Beaufort Sea, 1971-1975. Fish Mar Serv Res Dev Tech Rep 41

Wacasey JW, Atkinson EG, Glasspoole L (1979) Zoobenthos data from upper Frobisher Bay, 1967-1973. Can Data Rep Fish Aquat Sci 164

Wacasey JW, Atkinson EG, Glasspoole L (1980) Zoobenthos data from inshore stations of upper Frobisher Bay, 1969-1976. Can Data Rep Fish Aquat Sci 205

Wenzel M (2007) Benthic community structure in the Chirikov Basin, northern Bering Sea: A comparison between 1986 and 2002. MSc thesis, University of Marburg, Germany

Węsławski JM, Kendall MA, Włodarska-Kowalczuk M, Iken K, Kędra M, Legezynska J, Sejr MK (this issue) Arctic fjord and coastal macrobenthos biodiversity. Mar Biodiv

Witman JD, Cusson M, Archambault P, Pershing AJ, Mieskowska N (2008) The relation between productivity and species diversity in temperate-arctic marine ecosystems. Ecology 89:S66-S80 
Włodarska-Kowalczuk M, Kedra M (2007) Surrogacy in natural patterns of benthic distribution and diversity: selected taxa versus lower taxonomic resolution. Mar Ecol Prog Ser 351:53-63

Włodarska-Kowalczuk M, Kendall MA, Węsławski JM, Klages M, Soltwedel T (2004) Depth gradients of benthic standing stock and diversity on the continental margin at a high latitude ice-free site (off West Spitsbergen, $79^{\circ} \mathrm{N}$ ). Deep-Sea Res I 51:1903-1914

Włodarska-Kowalczuk M, Sicinski J, Gromisz S, Kendall MA, Dahle S (2007) Similar softbottom polychaete diversity in Arctic and Antarctic marine inlets. Mar Biol 151:607616

Zenkevitch LA (1963) Biology of the seas of the U.S.S.R. George Allen \& Unwin, London 


\section{Tables}

Table 1 The Arctic shelf ecoregions according to the "Marine Ecoregions of the World" (MEOW) scheme proposed by Spalding et al. (2007). MEOW number, name and spatial extent of ecoregions (in $1000 \mathrm{~km}^{2}$ ), number of stations and records (before validation) in our data.

\begin{tabular}{clccc}
$\begin{array}{c}\text { MEOW } \\
\#\end{array}$ & Ecoregion & Area $\left(\mathbf{1 0 0 0} \mathbf{~ k m}^{\mathbf{2}}\right)$ & Stations & Records \\
\hline 1 & North Greenland & 282 & 87 & 4385 \\
2 & North and East Iceland & 79 & 17 & 22 \\
3 & East Greenland Shelf & 365 & 19 & 545 \\
4 & West Greenland Shelf & 281 & 45 & 4495 \\
5 & Northern Grand Banks - Southern Labrador & 577 & 8 & 8 \\
6 & Northern Labrador & 239 & 50 & 4825 \\
7 & Baffin Bay - Davis Strait & 116 & 5 & 204 \\
8 & Hudson Complex & 1172 & 89 & 1380 \\
9 & Lancaster Sound & 230 & 3 & 86 \\
10 & High Arctic Archipelago & 360 & - & - \\
11 & Beaufort-Amundsen-Viscount-Melville & 464 & 131 & 4095 \\
12 & Beaufort Sea Shelf & 145 & 518 & 11030 \\
13 & Chukchi Sea & 605 & 337 & 8697 \\
14 & Eastern Bering Sea & 910 & 177 & 3823 \\
15 & East Siberian Sea & 906 & 155 & 946 \\
16 & Laptev Sea & 533 & 255 & 1737 \\
17 & Kara Sea & 900 & 567 & 3314 \\
18 & North and East Barents Sea & 1536 & 1799 & 14494 \\
19 & White Sea & 87 & 190 & 1052 \\
\hline & & $\mathbf{9 7 8 7}$ & $\mathbf{4 4 5 2}$ & $\mathbf{6 5 1 3 8}$ \\
\hline
\end{tabular}


Table 2 Macro- and megabenthic species diversity of Arctic shelf ecoregions. Number of stations, observed number of species $\left(\mathrm{S}_{\mathrm{obs}}\right)$, rarefied number of species to be expected in 19 samples $\left(\mathrm{RS}_{19}\right) \pm$ standard deviation, average taxonomic distinctness values $\left(\Delta^{+}\right)$, and Chao2 estimates of expected total species numbers $( \pm$ standard deviation). a) Mollusca, Arthropoda and Echinodermata combined. b) Annelida only.

a)

\begin{tabular}{|clc|c|cc|c|cc|}
\hline MEOW \# & Ecoregion & $\begin{array}{c}\text { \# of } \\
\text { Stations }\end{array}$ & S $_{\text {obs }}$ & RS $_{19}$ & $\mathbf{\pm}$ SD & $\Delta^{+}$ & Chao2 & $\mathbf{\pm}$ SD \\
\hline 1 & N Greenland & 87 & 355 & 201 & 27 & 70.5 & 478 & 30 \\
3 & E Greenland & 19 & 40 & 40 & 0 & 72.8 & 55 & 9 \\
4 & W Greenland & 45 & 332 & 239 & 22 & 69.9 & 432 & 24 \\
6 & N Labrador & 50 & 406 & 299 & 25 & 70.9 & 591 & 38 \\
8 & Hudson & 89 & 290 & 118 & 43 & 70.7 & 483 & 43 \\
11 & Amundsen & 131 & 364 & 181 & 16 & 74.4 & 482 & 22 \\
12 & Beaufort & 518 & 455 & 97 & 24 & 73.4 & 745 & 47 \\
13 & Chukchi & 337 & 401 & 146 & 23 & 74.0 & 443 & 13 \\
14 & E Bering & 176 & 146 & 66 & 9 & 75.2 & 204 & 23 \\
15 & E Siberian & 155 & 113 & 43 & 6 & 71.9 & 161 & 21 \\
16 & Laptev & 255 & 216 & 61 & 21 & 72.8 & 311 & 29 \\
17 & Kara & 567 & 164 & 43 & 8 & 67.5 & 219 & 22 \\
18 & NE Barents & 1798 & 586 & 62 & 26 & 72.3 & 712 & 24 \\
19 & White & 190 & 73 & 27 & 3 & 69.1 & 117 & 23 \\
\hline
\end{tabular}

b)

\begin{tabular}{|clc|c|cc|c|cc|}
\hline MEOW \# & Ecoregion & $\begin{array}{c}\text { \# of } \\
\text { Stations }\end{array}$ & $\mathbf{S}_{\text {obs }}$ & RS $_{\mathbf{1 9}}$ & $\mathbf{\pm}$ SD & $\Delta^{+}$ & Chao2 & $\mathbf{\pm}$ SD \\
\hline 1 & N Greenland & 87 & 104 & 47 & 16 & 54.2 & 157 & 21 \\
3 & E Greenland & 19 & 88 & 88 & 0 & 54.5 & 123 & 17 \\
4 & W Greenland & 45 & 292 & 211 & 23 & 54.2 & 390 & 27 \\
6 & N Labrador & 50 & 218 & 165 & 15 & 54.7 & 274 & 19 \\
8 & Hudson & 89 & 131 & 57 & 17 & 54.4 & 193 & 22 \\
11 & Amundsen & 131 & 185 & 93 & 12 & 55.1 & 250 & 25 \\
12 & Beaufort & 518 & 305 & 108 & 21 & 54.7 & 349 & 17 \\
13 & Chukchi & 337 & 188 & 61 & 19 & 54.1 & 243 & 21 \\
14 & E Bering & 176 & 24 & 21 & 1 & 55.3 & 24 & 0 \\
15 & E Siberian & 155 & 28 & 3 & 9 & 54.4 & 28 & 0 \\
16 & Laptev & 255 & 31 & 5 & 6 & 54.0 & 40 & 7 \\
18 & NE Barents & 1798 & 322 & 29 & 36 & 54.5 & 355 & 12 \\
\hline
\end{tabular}




\section{Figures}

Fig. 1 The Arctic region, with the location of shelf ecoregions defined in the "Marine Ecoregions of the World" (MEOW) scheme proposed by Spalding et al. (2007). MEOW numbers are explained in Table 1.

Fig. 2 Taxonomic composition of the entire macro- and megabenthic fauna of the Arctic shelf regions at phylum level (a), Annelida (b), Mollusca (c) and Echinodermata (d) at class level, and Arthropoda (e) at order level.

Fig. 3 Bar graphs showing the observed number of macro- and megabenthic species ( $\left.\mathrm{S}_{\mathrm{obs}}\right)$ in Arctic shelf ecoregions, as well as the rarefied number of species expected to be recorded in each ecoregion if only 19 samples had been taken $\left(\mathrm{RS}_{19}\right)$ and Chao2 estimates of expected number of species. a) Mollusca, Arthropoda and Echinodermata combined, b) Annelida only (ND: no data for Kara and White Seas). $\mathrm{RS}_{19}$ and Chao2 values \pm standard deviation in 400 random permutations.

Fig. 4 Relationships between overall benthic species number (S), average taxonomic distinctness $\left(\Delta^{+}\right)$and sampling intensity, estimated by number of stations $(\mathrm{N})$ from Arctic shelf ecoregions. a-b: Mollusca, Arthropoda, and Echinodermata combined (a: $\mathrm{S}$ versus $\mathrm{N}$ (logarithmic scale), Spearman's rank correlation $\rho=0.288, P=$ 0.318 ; b: $\Delta^{+}$versus N (logarithmic scale), $\rho=0.027, P=0.674$ ). c-d: Annelida only (c: $\mathrm{S}$ versus $\mathrm{N}$ (logarithmic scale), $\rho=0.210, P=0.513$; d: $\Delta^{+}$versus $\mathrm{N}$ (logarithmic scale), $\rho=0.011, P=0.974$ ).

Fig. 5 Relationship between average taxonomic distinctness values $\left(\Delta^{+}\right.$; in the figure: Delta + ) and observed macro- and megabenthic species numbers in Arctic shelf ecoregions for a) Mollusca, Arthropoda and Echinodermata combined and b) Annelida only. The plots show the mean $\Delta^{+}$value and $95 \%$ probability limits, computed for 1000 frequency-based simulations of sub-samples of varying size (a: 10 to 600 species; 10 to 400 species) drawn from a presumed 'pan-Arctic' species pool consisting of the total of a) 1562 mollusk, arthropod and echinoderm species and b) 668 annelid species contained in our dataset.

Fig. 6 Station-based rarefaction curves (average curves from 400 permutations; doublelogarithmic scale) for Arctic shelf ecoregions. (a) Mollusca, Arthropoda, and 
Echinodermata combined; (b) Annelida only.

Fig. 7 Multidimensional scaling plots. a-f: Faunal resemblance patterns among Arctic shelf ecoregions, analyzed at the level of species (a), genera (b), and families (c) of Mollusca, Arthropoda, and Echinodermata combined (14 ecoregions), and species (d), genera (e), and families (f) of Annelida only. g: Second-stage analysis of between-ecoregion resemblance patterns of different taxonomic groups (Mollusca, Arthropoda, Echinodermata; Mollusca, Arthropoda and Echinodermata combined; Annelida) at different taxonomic levels (species, genus, and family) for the nine ecoregions considered in the annelid resemblance analysis. 
Fig.1

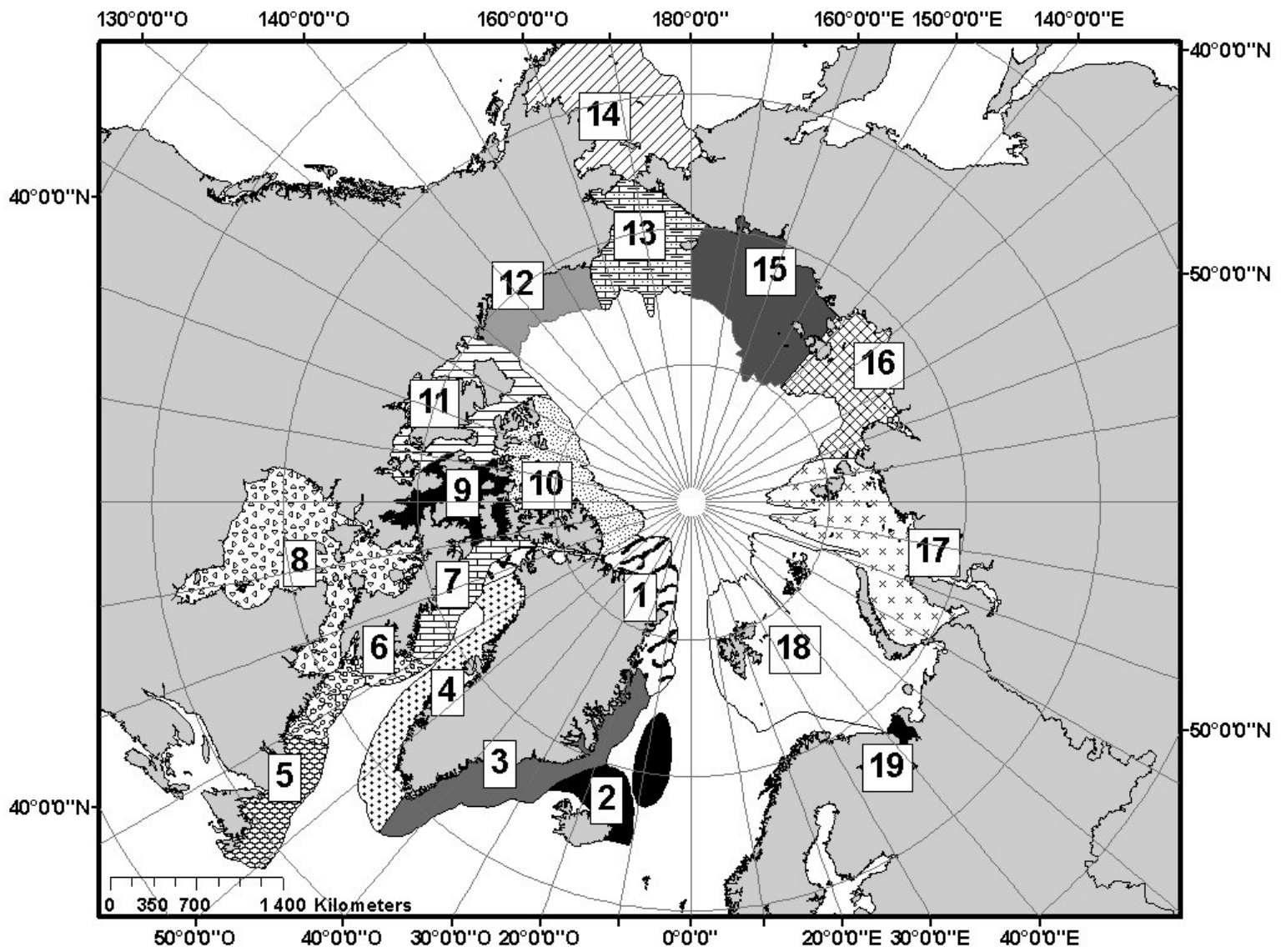


Fig. 2

1038

\section{Echinodermata}

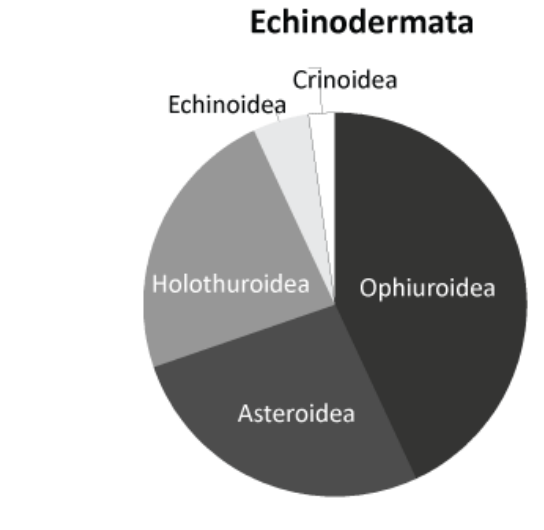

1039
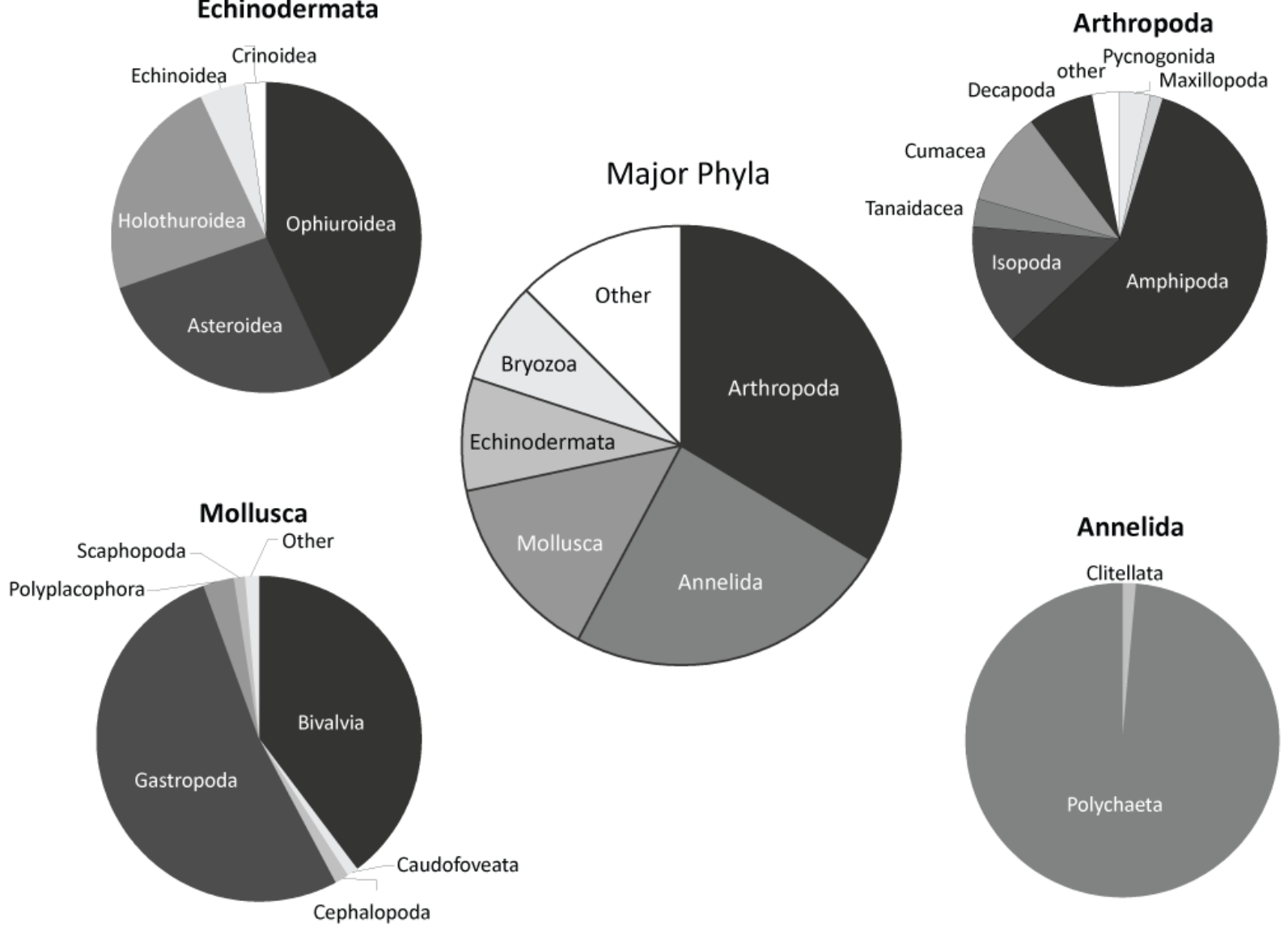

1040 
Fig. 3a

Arctic Shelf Benthos (Mollusca, Arthropoda and Echinodermata)

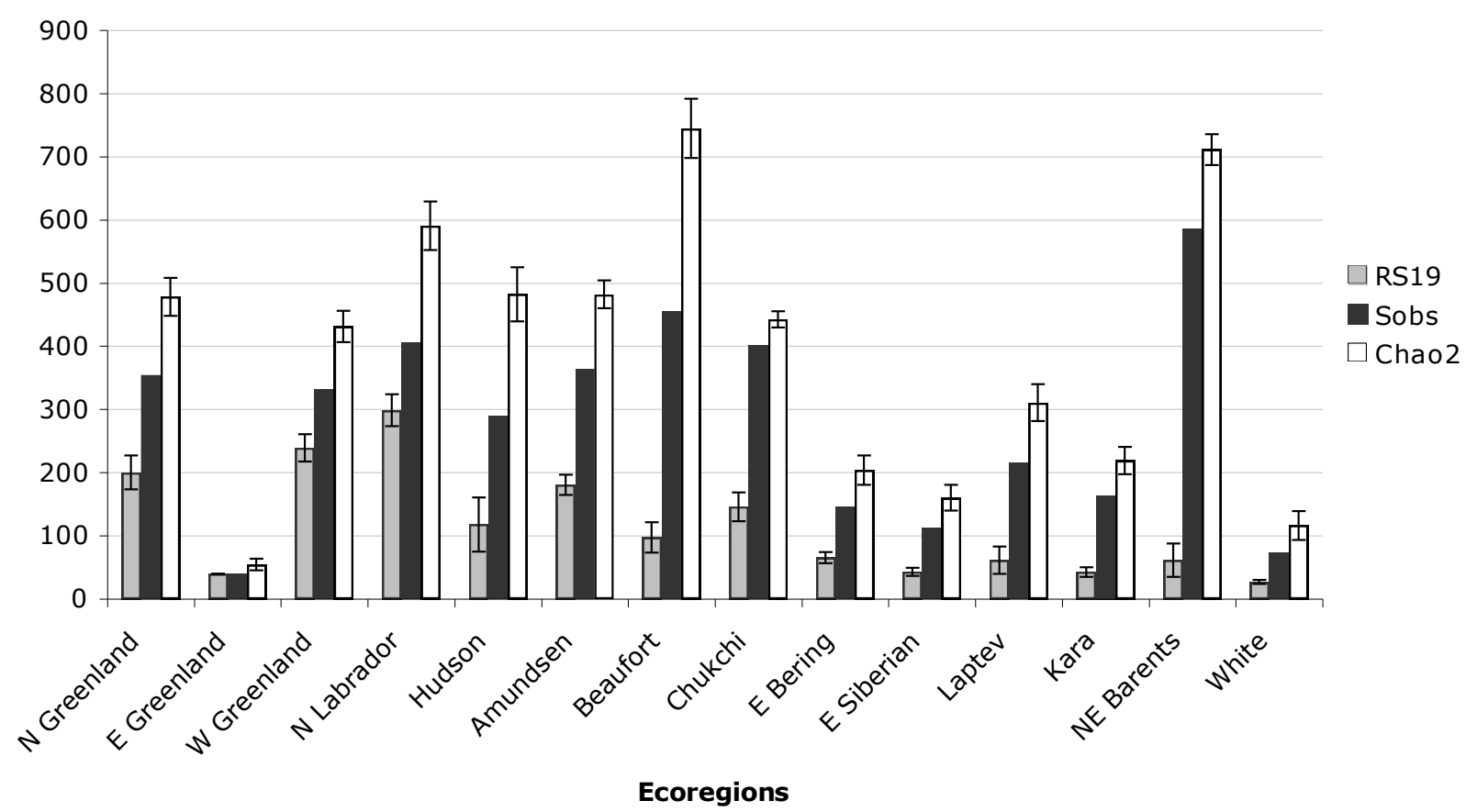

Fig. 3b

\section{Arctic Shelf Benthos (Annelida)}

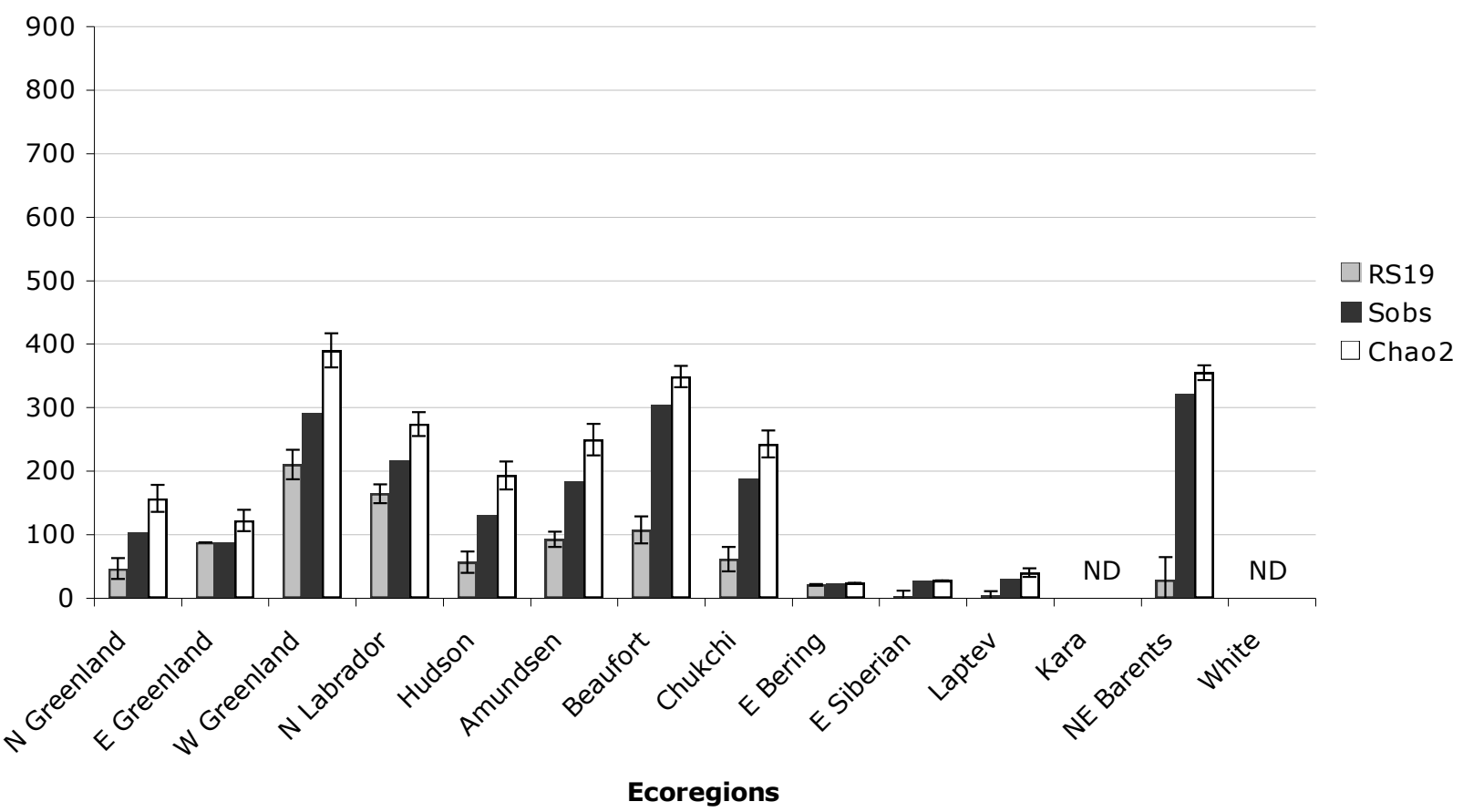


Fig. 4a

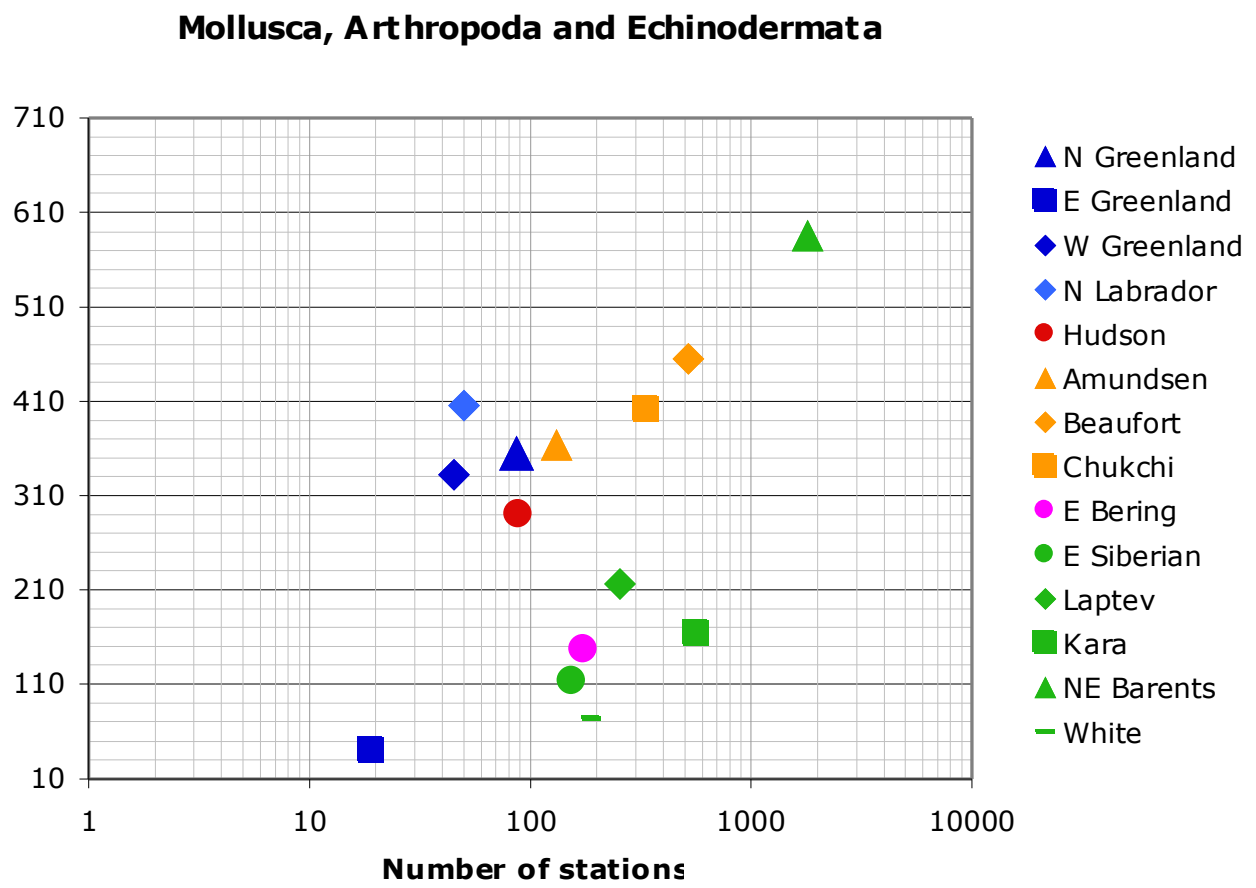

Fig. 4b

Mollusca, Arthropoda and Echinodermata

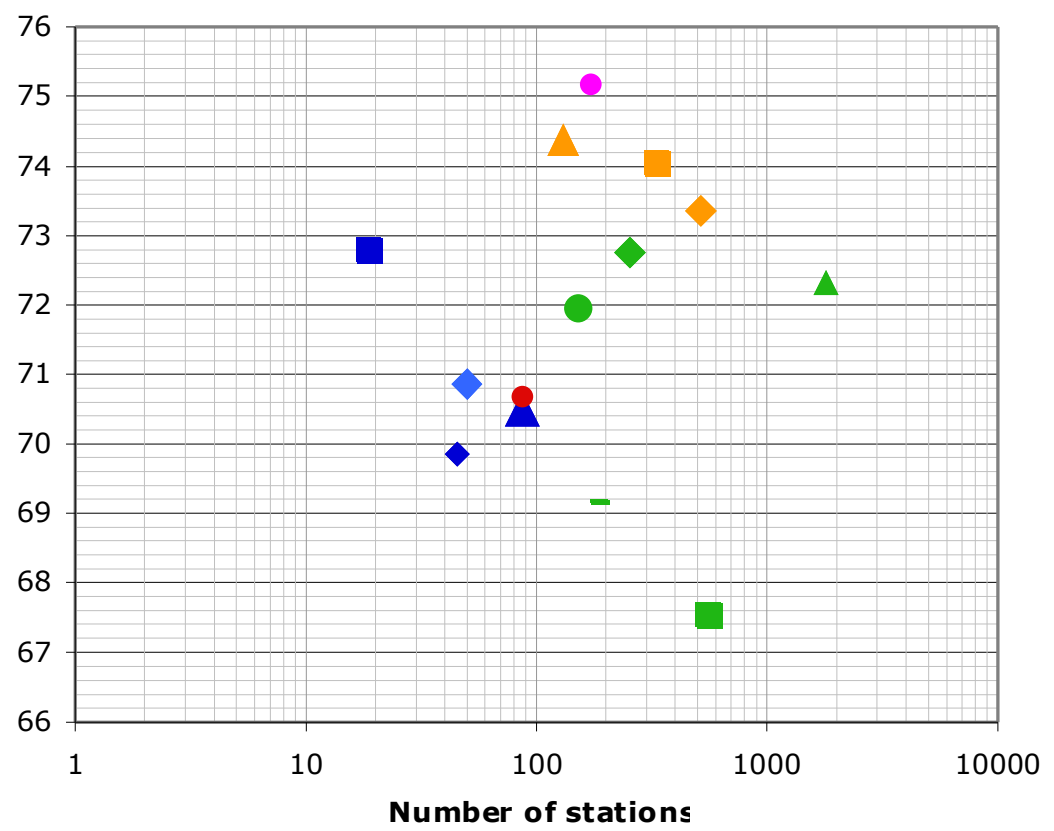

$\Delta$ N Greenland

E Greenland

- W Greenland

$\checkmark$ N Labrador

- Hudson

$\triangle$ Amundsen

$\checkmark$ Beaufort

Chukchi

- E Bering

- E Siberian

$\checkmark$ Laptev

Kara

$\triangle$ NE Barents

- White 
Fig. 4c

\section{Annelida}

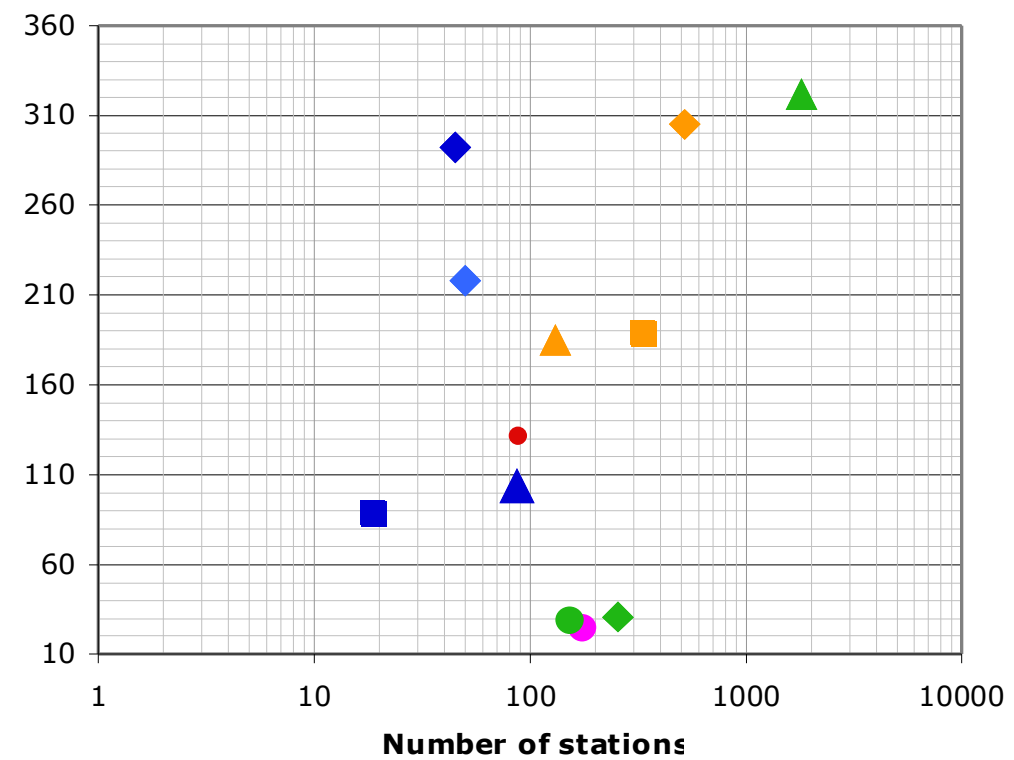

$\Delta \mathrm{N}$ Greenland

E Greenland

- W Greenland

- N Labrador

- Hudson

Amundsen

$\checkmark$ Beaufort

Chukchi

- E Bering

- East Siberian Sea

- Laptev

$\triangle$ NE Barents

Fig. 4d

\section{Annelida}

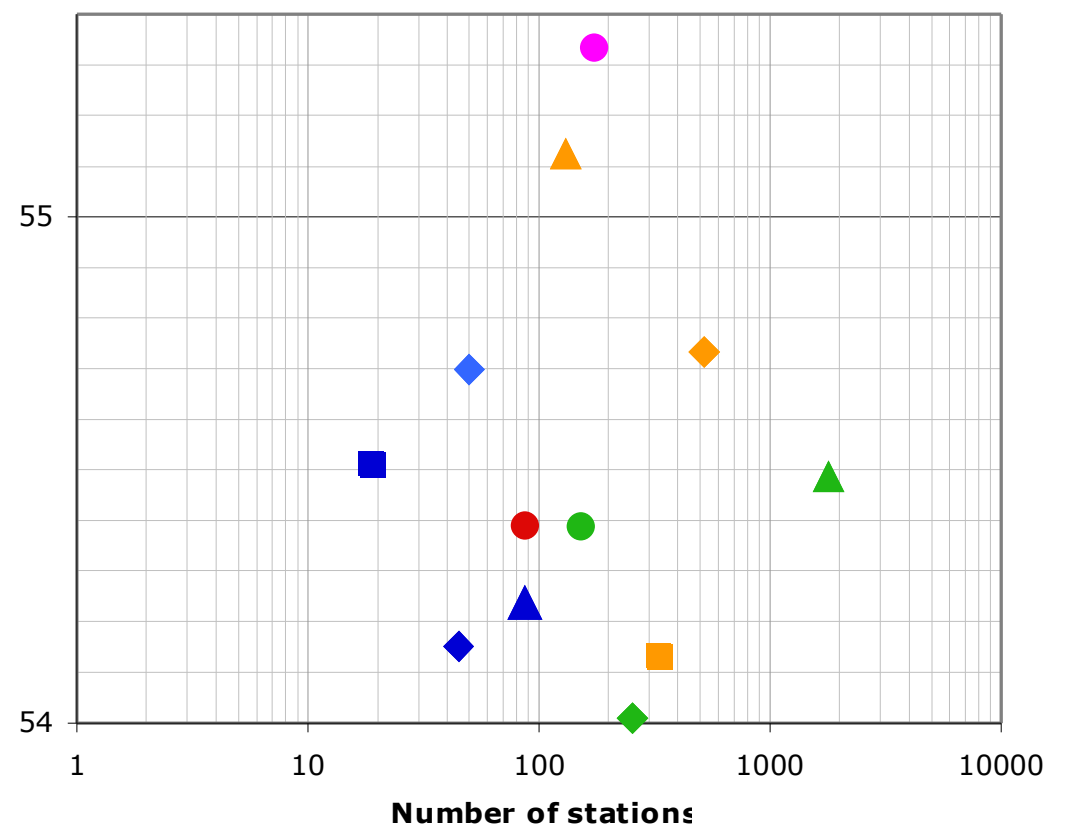

$\Delta \mathrm{N}$ Greenland

E Greenland

- W Greenland

$\checkmark$ N Labrador

- Hudson

$\triangle$ Amundsen

$\checkmark$ Beaufort

Chukchi

- E Bering

- E Siberian

$\checkmark$ Laptev

$\triangle$ NE Barents 
Fig. 5a

Arctic Shelf Benthos (Mollusca, Arthropoda, and Echinodermata) Average Taxonomic Distinctness

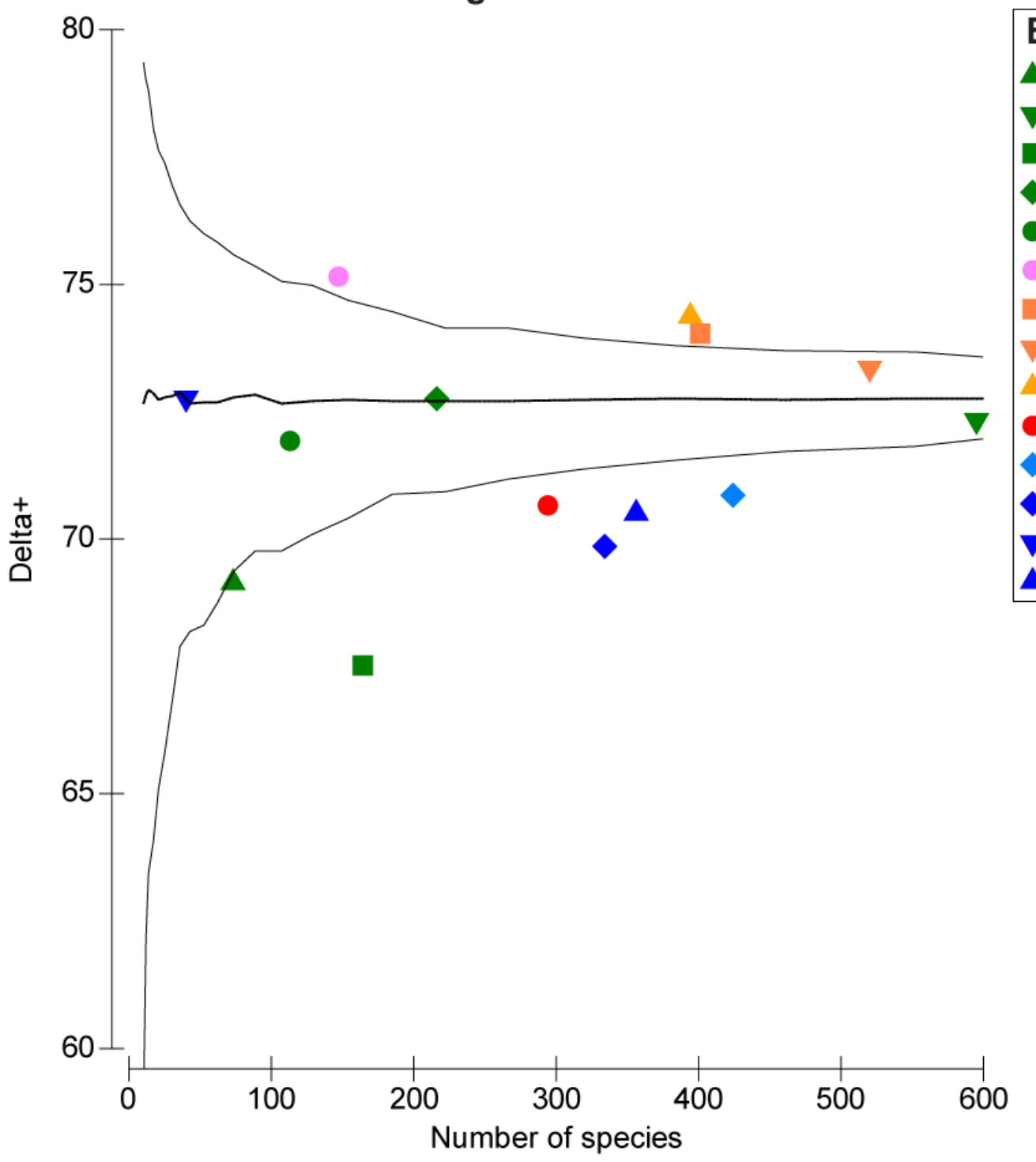

Ecoregions

$\triangle$ White

$\nabla$ NE Barents

Kara

Laptev

- E Siberian

- E Bering

Chukchi

Beaufort

Amundsen

Hudson

N Labrador

W Greenland

- E Greenland

$\Delta \mathrm{N}$ Greenland 
Fig. 5b

\section{Arctic Shelf Benthos (Annelida)} Average Taxonomic Distinctness Delta+

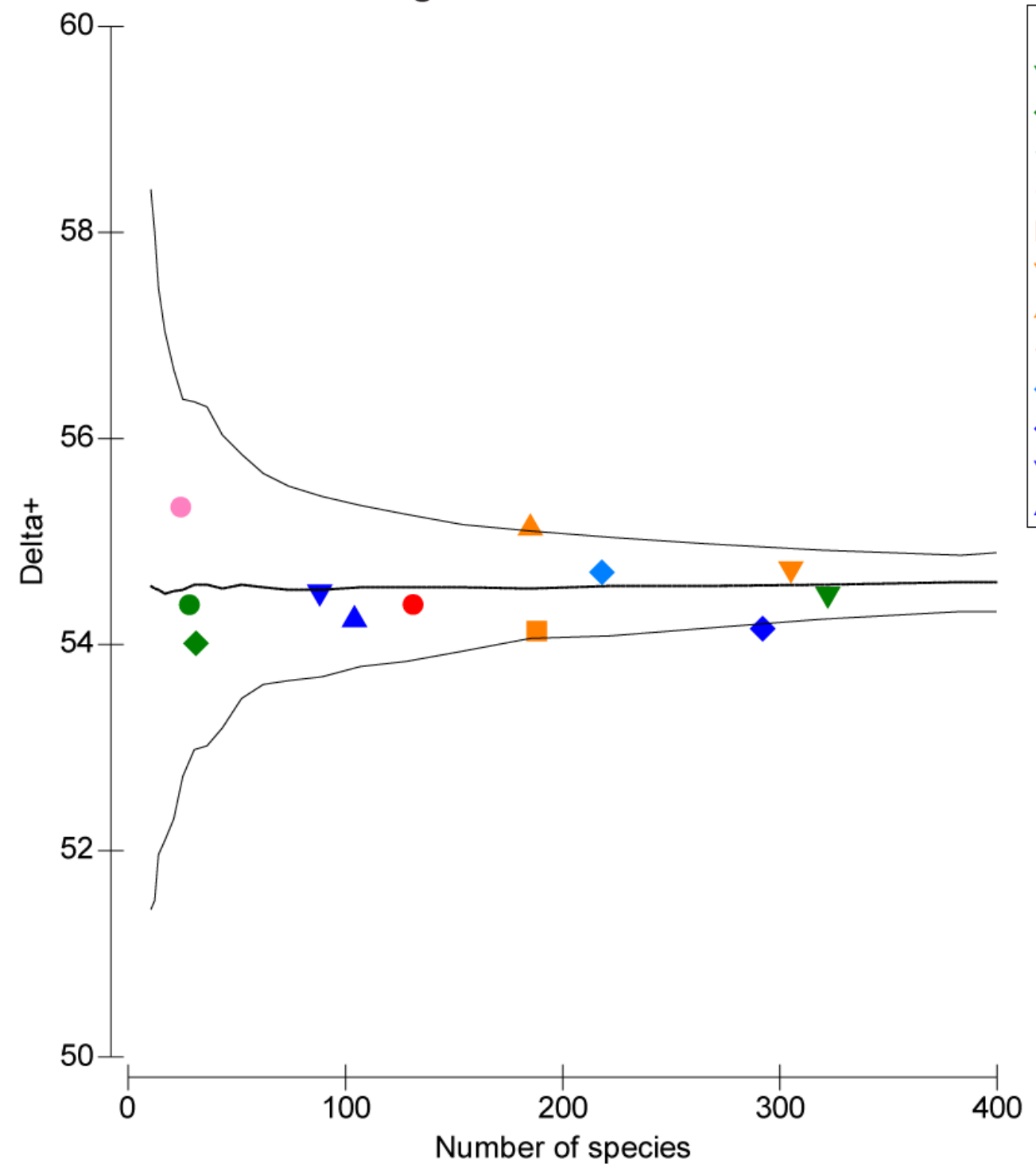

Ecoregions $\checkmark$ NE Barents

Laptev

- E Siberian

E Bering

Chukchi

Beaufort

Amundsen

- Hudson

N Labrador

W Greenland

E Greenland

$\Delta$ N Greenland

Number of species 
Fig. 6a

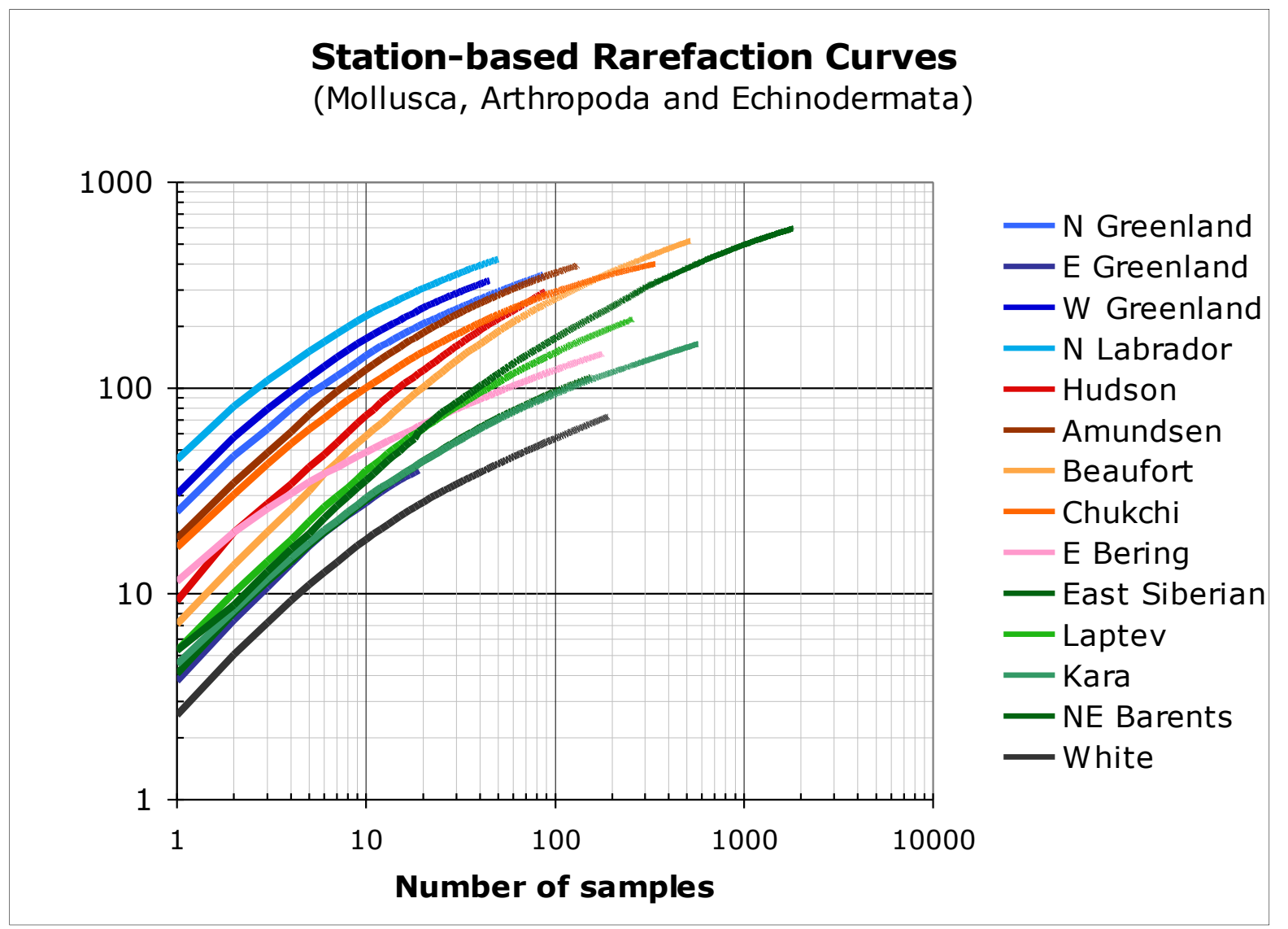

Fig. 6b

\section{Station-based Rarefaction Curves}

(Annelida)

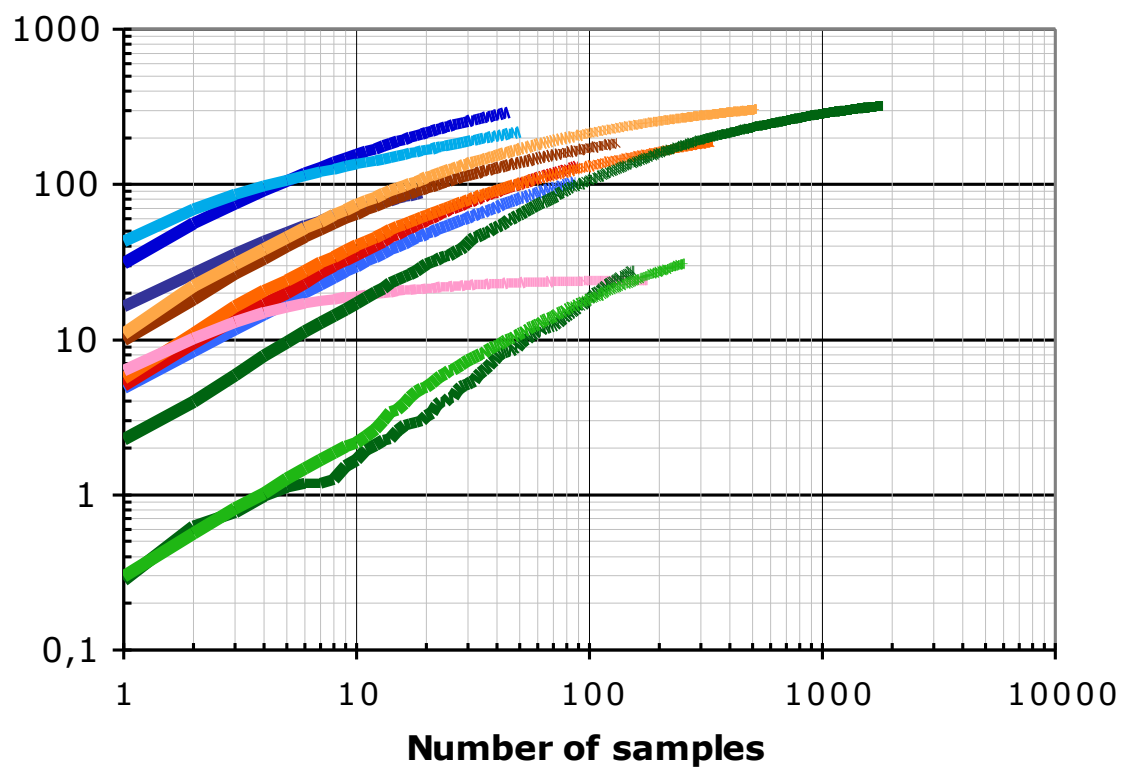

N Greenland

E Greenland

W Greenland

N Labrador

Hudson

Amundsen

Beaufort

Chukchi

E Bering

East Siberian

Laptev

NE Barents 
Fig. 7 a

Arctic Shelf Benthos (Mollusca, Arthropoda, Echinodermata) Resemblances at species level

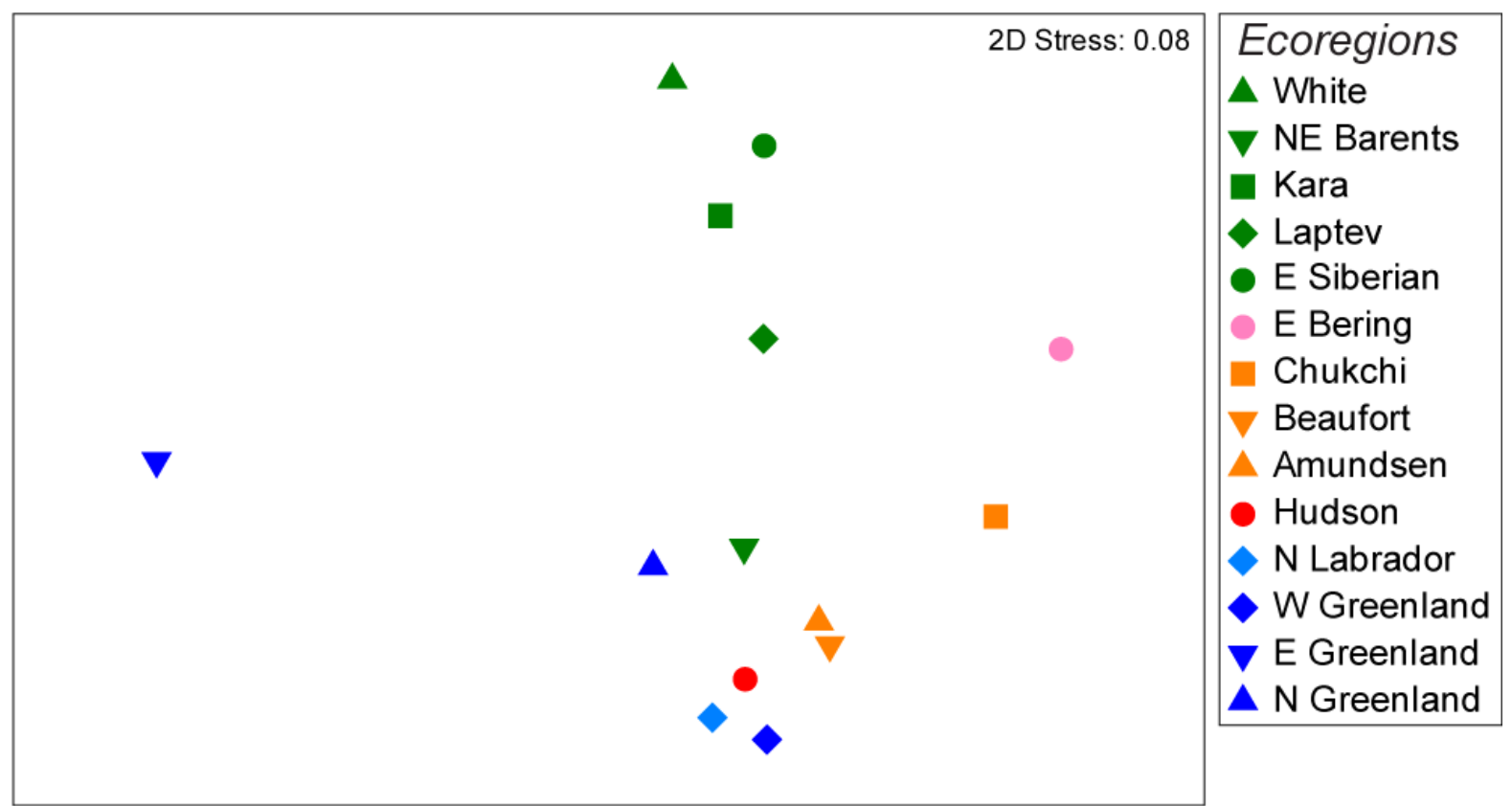

Fig. $7 b$

Arctic Shelf Benthos (Mollusca, Arthropoda, Echinodermata) Resemblances at genus level

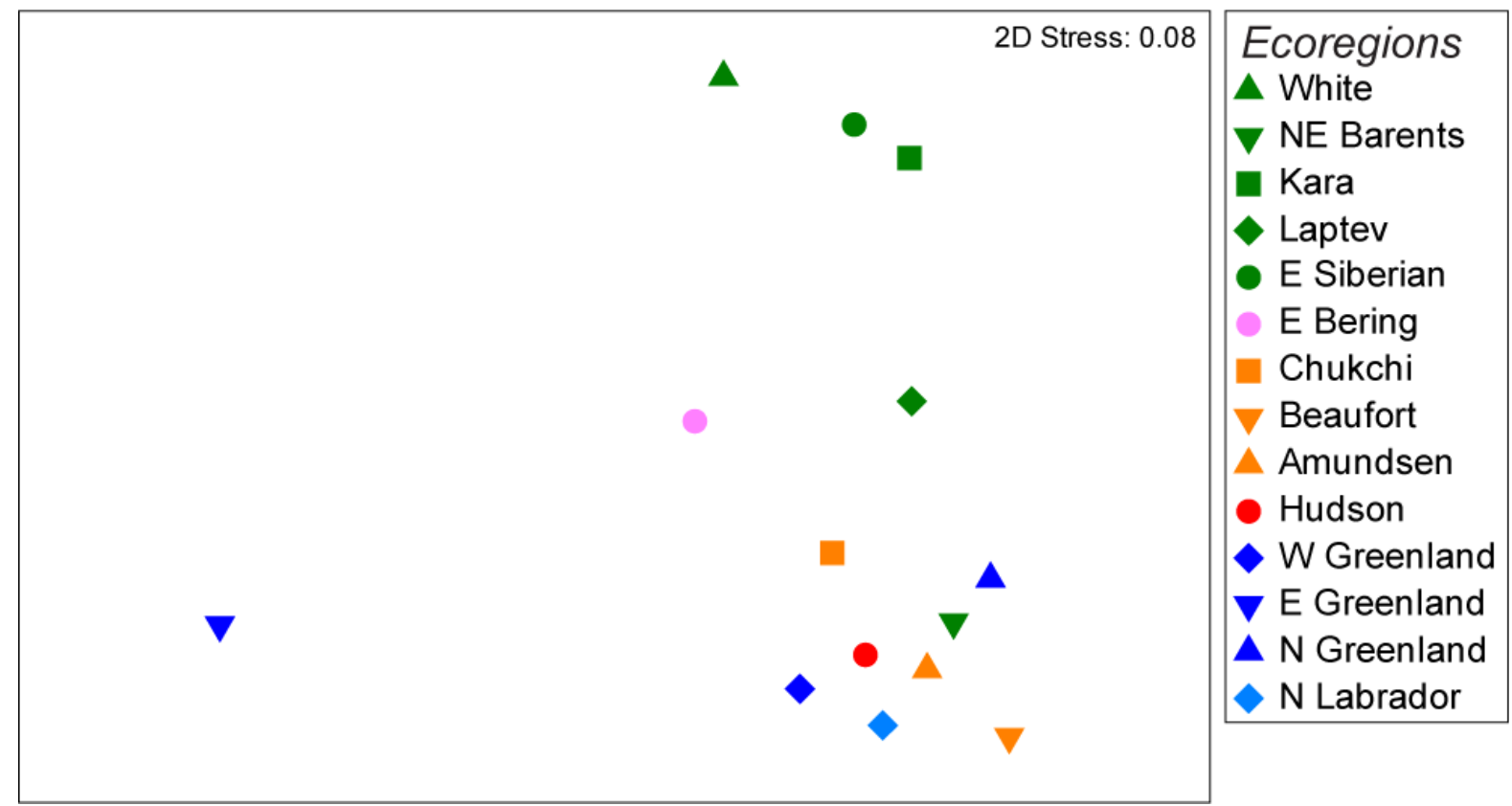


$1081 \quad$ Fig. 7c

Arctic Shelf Benthos (Mollusca, Arthropoda, Echinodermata) Resemblances at family level

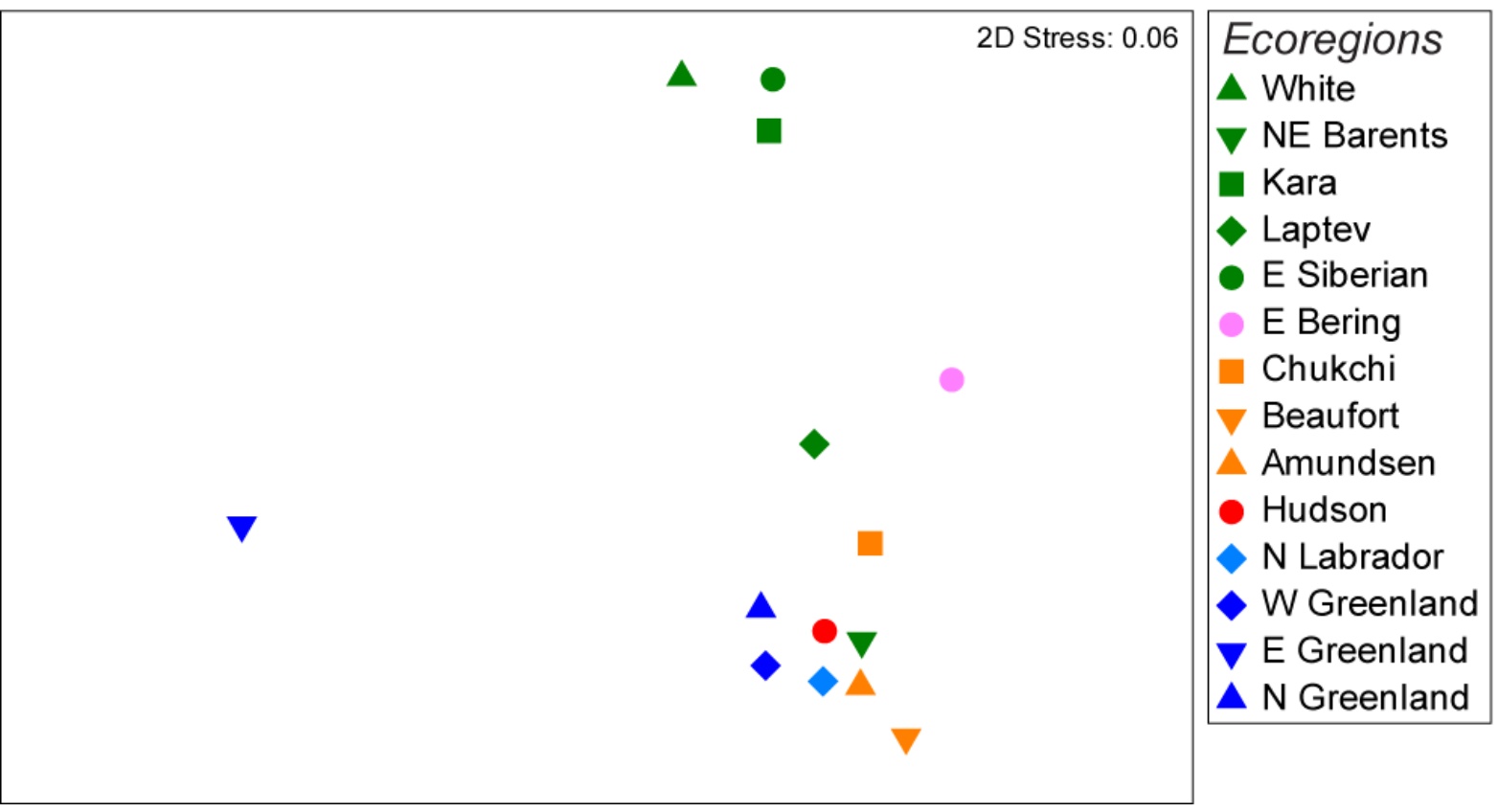


Fig. 7d

\section{Arctic Shelf Benthos (Annelida) \\ Resemblances at species level}

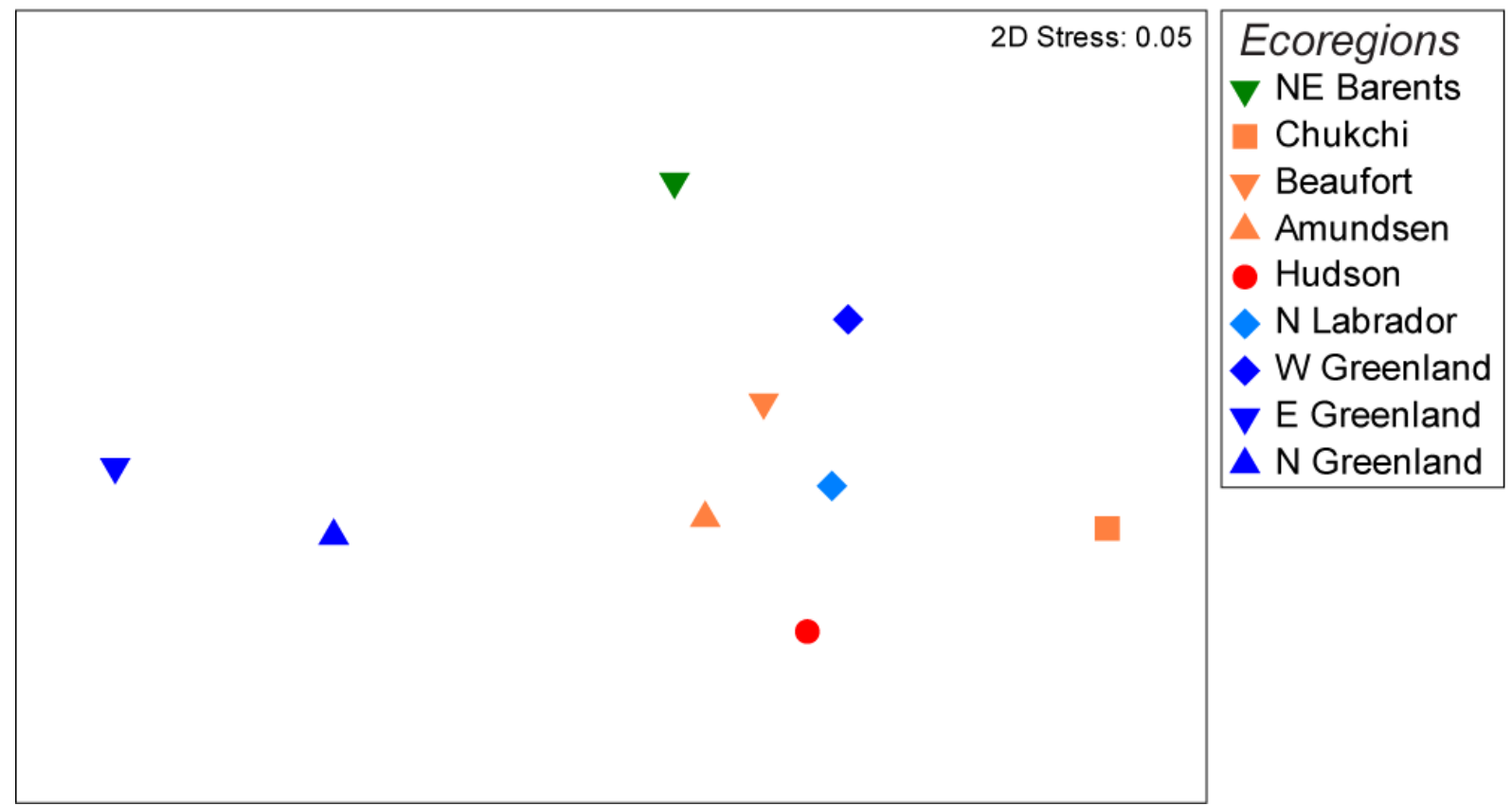

Fig. 7e

\section{Arctic Shelf Benthos (Annelida) \\ Resemblances at genus level}

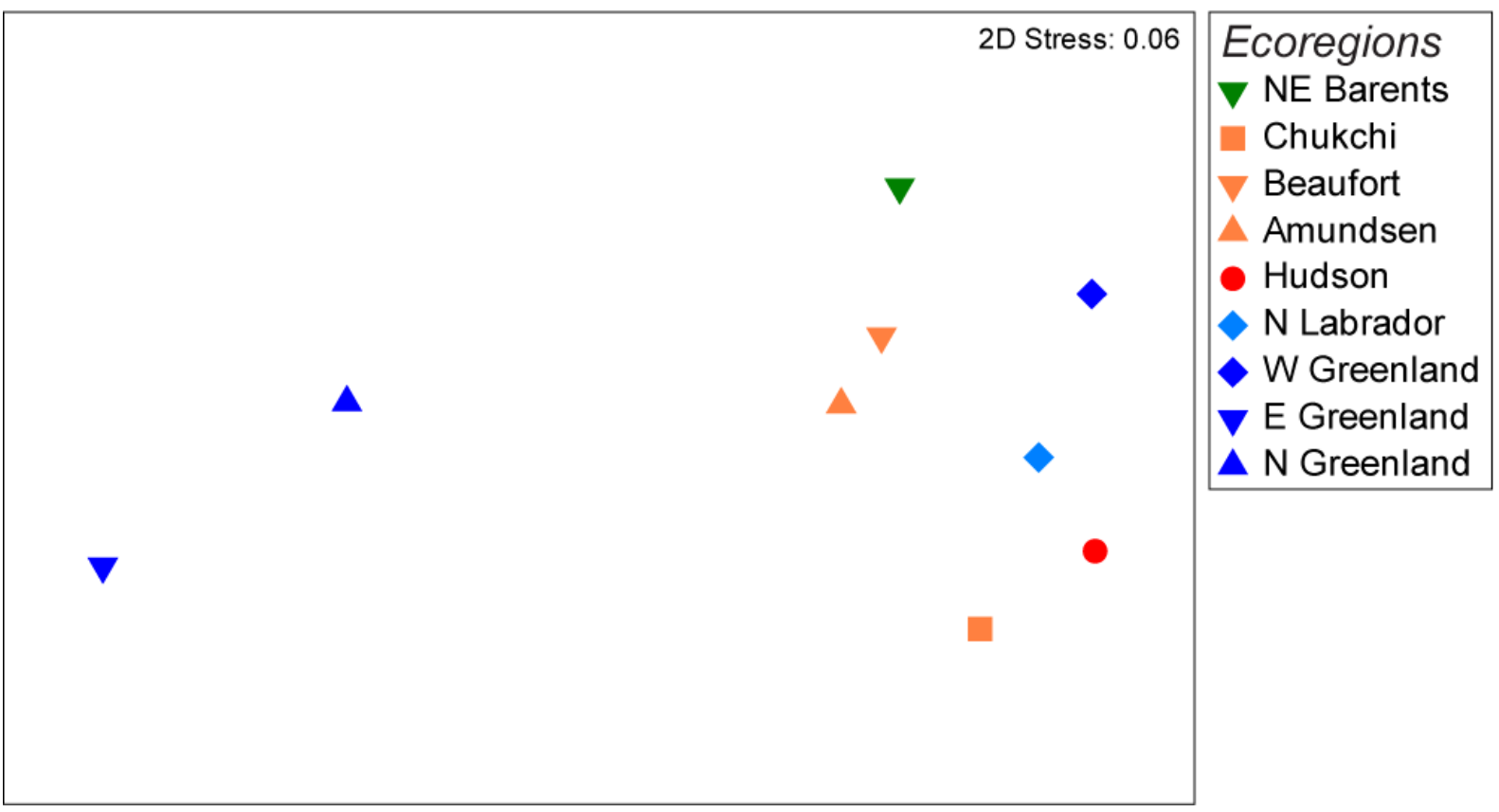


Fig. 7f

\section{Arctic Shelf Benthos (Annelida) \\ Resemblances at family level}

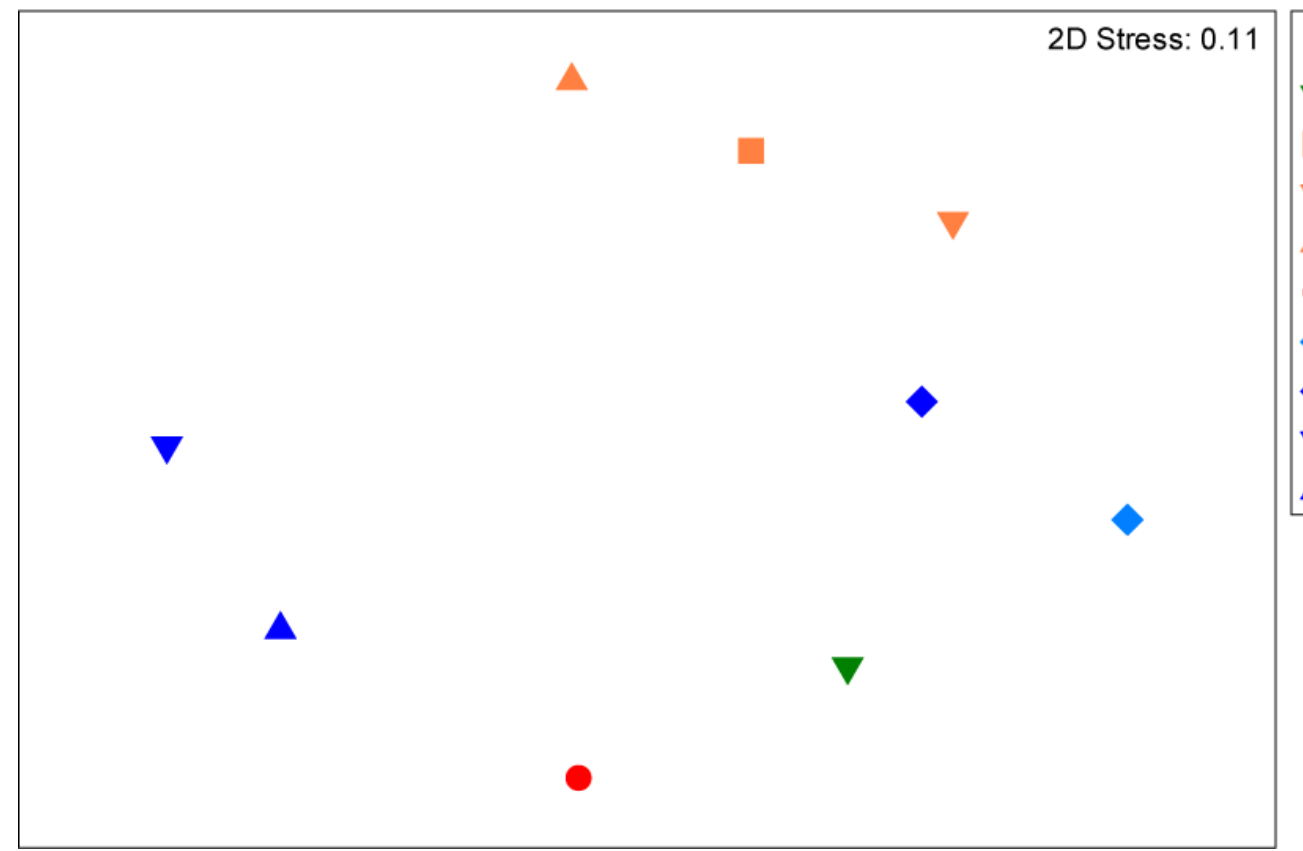

Ecoregions

$\checkmark$ NE Barents

Chukchi

Beaufort

Amundsen

- Hudson

N Labrador

- W Greenland

$\checkmark$ E Greenland

$\Delta \mathrm{N}$ Greenland

Fig. $7 g$

\section{Arctic Shelf Benthos}

(Mollusca, Arthropoda, Annelida, Echinodermata)

Second-stage Analysis of Between-Ecoregion Resemblances

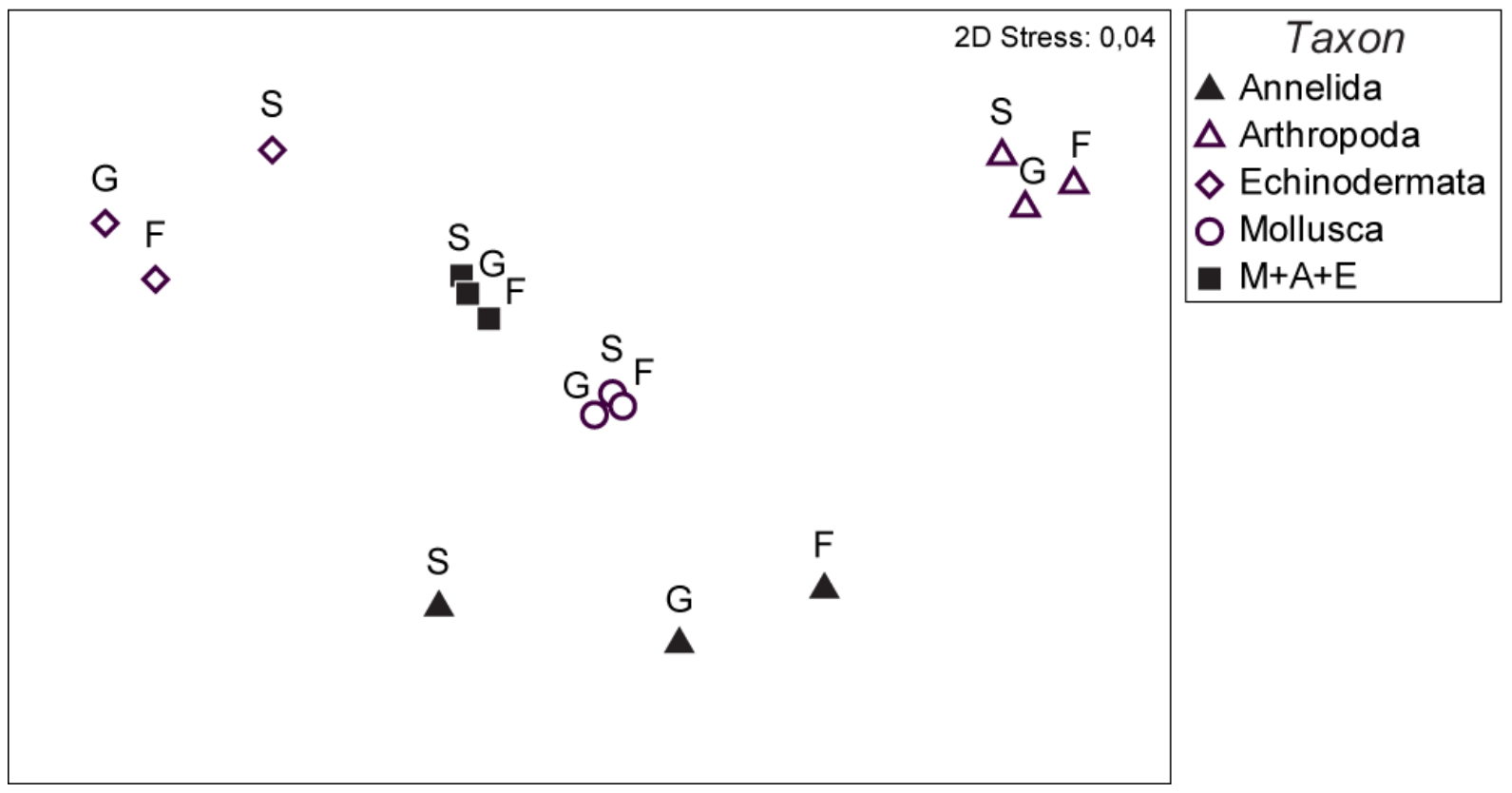

